Prepared in cooperation with the U.S. Army Corps of Engineers

\title{
Geomorphic Classification and Evaluation of Channel Width and Emergent Sandbar Habitat Relations on the Lower Platte River, Nebraska
}

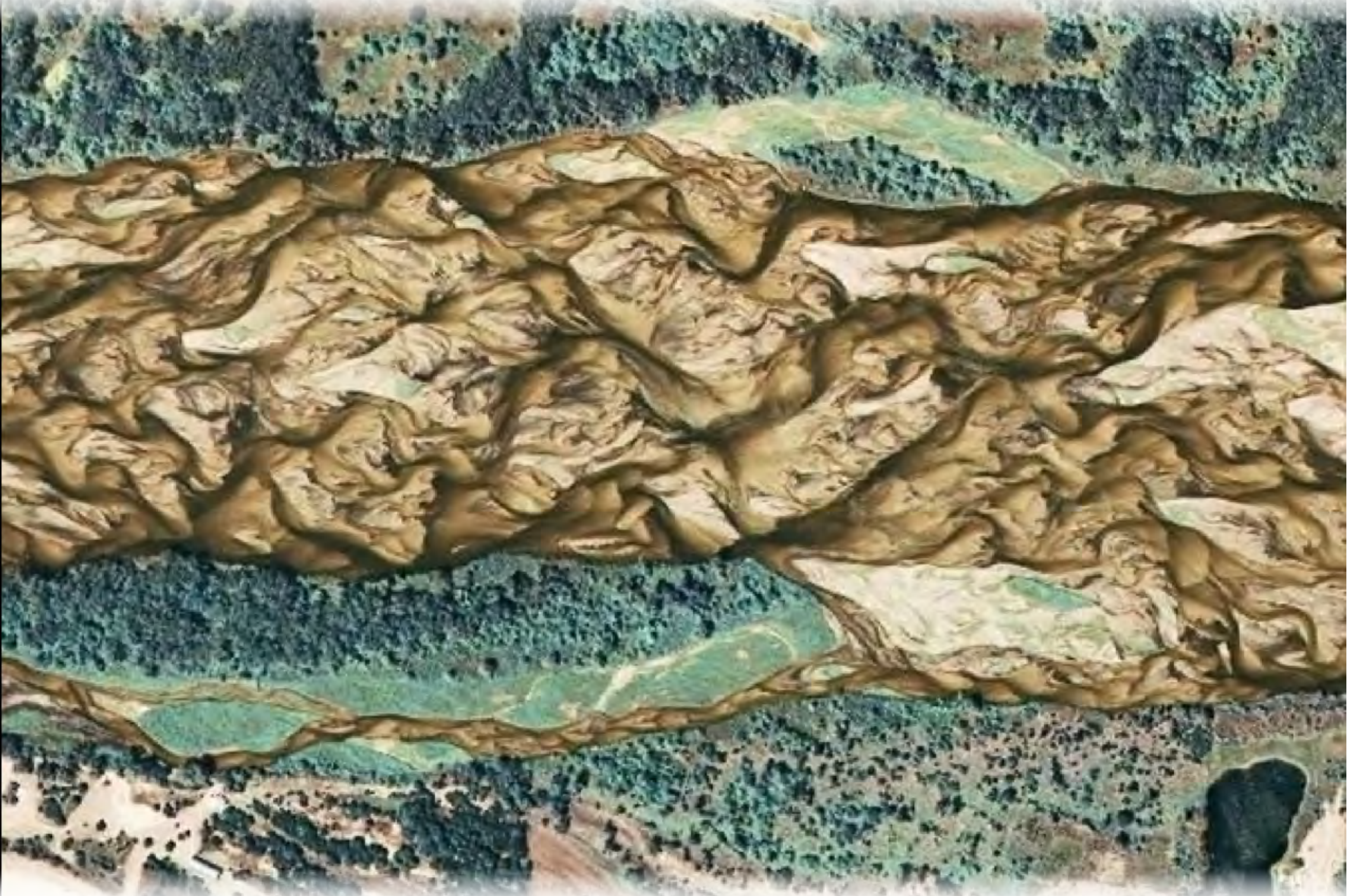

Scientific Investigations Report 2011-5028 
Cover photograph: 2006 National Aerial Imagery Program imagery of Lower Platte River near river mile 71. 


\section{Geomorphic Classification and Evaluation of Channel Width and Emergent Sandbar Habitat Relations on the Lower Platte River, Nebraska}

By Caroline M. Elliott

In cooperation with the U.S. Army Corps of Engineers

Scientific Investigations Report 2011-5028

U.S. Department of the Interior

U.S. Geological Survey 


\title{
U.S. Department of the Interior \\ KEN SALAZAR, Secretary \\ U.S. Geological Survey \\ Marcia K. McNutt, Director
}

\section{U.S. Geological Survey, Reston, Virginia: 2011}

\author{
This and other USGS information products are available at http://store.usgs.gov/ \\ U.S. Geological Survey \\ Box 25286, Denver Federal Center \\ Denver, CO 80225 \\ To learn about the USGS and its information products visit http://www.usgs.gov/ \\ 1-888-ASK-USGS
}

\begin{abstract}
Any use of trade, product, or firm names is for descriptive purposes only and does not imply endorsement by the U.S. Government.

Although this report is in the public domain, permission must be secured from the individual copyright owners to reproduce any copyrighted materials contained within this report.
\end{abstract}

Suggested citation:

Elliott, C.M., 2011, Geomorphic classification and evaluation of channel width and emergent sandbar habitat relations on the Lower Platte River, Nebraska: U.S. Geological Survey Scientific Investigations Report 2011-5028, 22 p. 


\section{Contents}

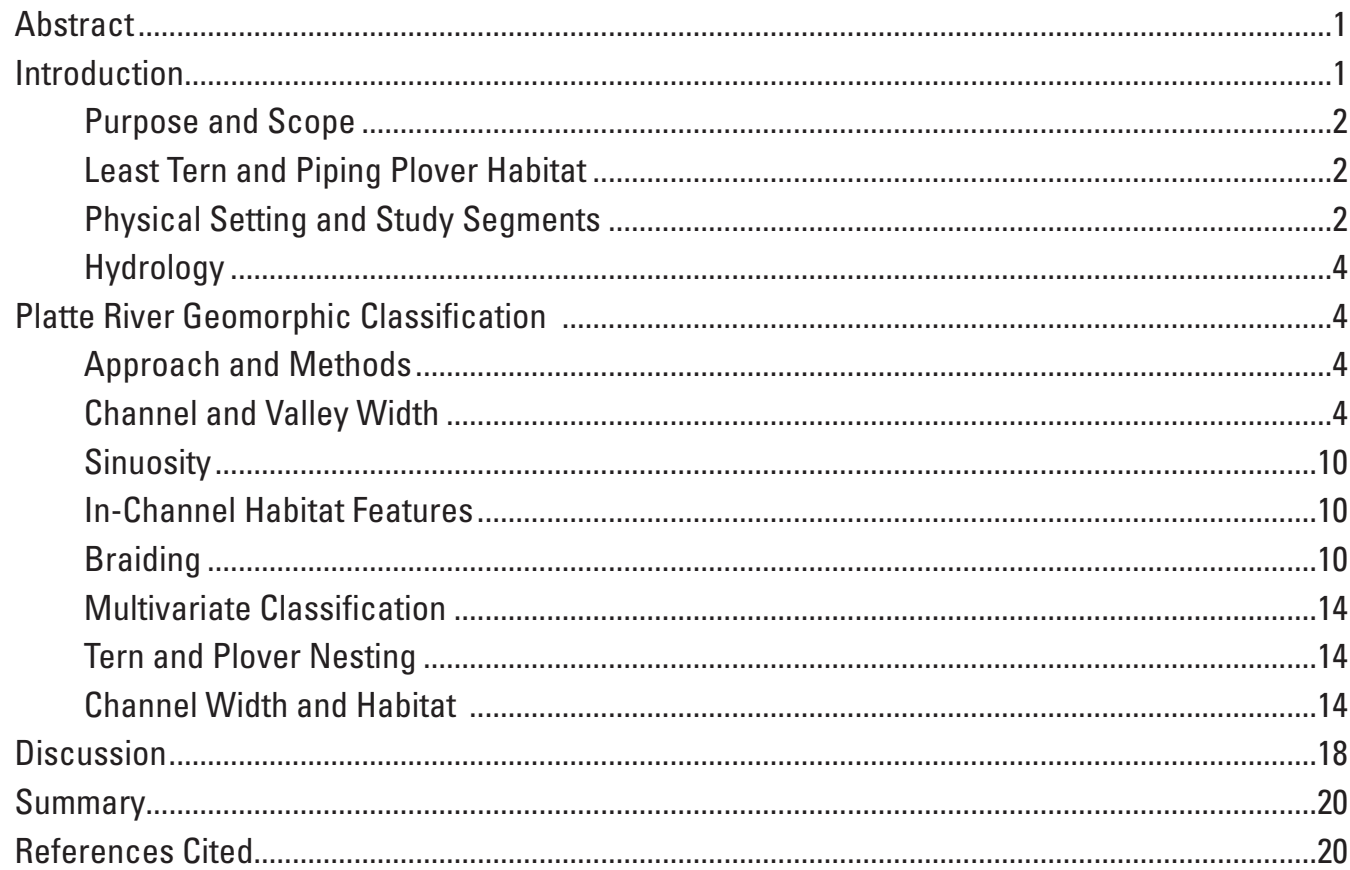

\section{Figures}

1. Map showing the Platte River Basin and the Lower Platte River study area ...................3

2. Graph showing discharge for the Lower Platte River and tributaries...............................5

3. Graph showing locations and discharges for the Lower Platte River for 2006 National Aerial Imagery Program photographs used in this study at the North Bend and Louisville streamflow gages on the Platte River, Nebraska...

4. Graph showing Lower Platte River geomorphic characteristics including valley width, channel width, sinuosity, sandbar count, channel count index, and percent of channel composition

5. Plots showing box and whisker plots of Lower Platte River geomorphic characteristics summarized by segment

6. Map showing comparison of National Aerial Imagery Program (NAIP) photography, manual classification, and computerized classification for a 1.25-mile representative reach of the Lower Platte River

7. Plots showing box and whisker plots of percent of channel type from supervised imagery classification by segment for the Lower Platte River

8. Map showing examples of four- and seven-cluster classifications on the Lower Platte River

9. Graph showing cumulative distribution of channel width and occurrence of habitat units 


\section{Tables}

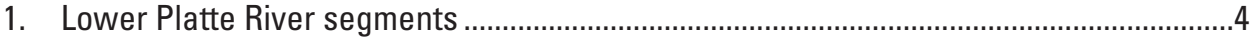

2. Dates and river discharges for 2006 digital photography ..............................................

3. Lower Platte River geomorphic attributes summarized by

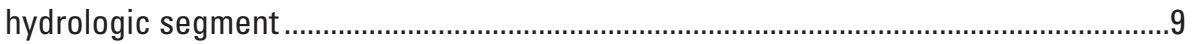

4. Names and interpreted physical significance of clustered classes ..............................16

5. Percent of classification reaches in Lower Platte River segments from Elliott and others, 2009 .................................................................................. 17

6. Nests per mile in Lower Platte River segments ............................................................17

\section{Conversion Factors}

Inch/Pound to SI

\begin{tabular}{lll}
\hline \multicolumn{1}{c}{ Multiply } & \multicolumn{1}{c}{ By } & \multicolumn{1}{c}{ To obtain } \\
\hline \multicolumn{2}{c}{ Length } \\
foot $(\mathrm{ft})$ & 0.3048 & meter $(\mathrm{m})$ \\
mile $(\mathrm{mi})$ & 1.609 & kilometer $(\mathrm{km})$ \\
\hline \multicolumn{2}{c}{ Flow rate } & \\
\hline cubic foot per second $\left(\mathrm{ft}^{3} / \mathrm{s}\right)$ & 0.02832 & cubic meter per second $\left(\mathrm{m}^{3} / \mathrm{s}\right)$ \\
\hline
\end{tabular}

Horizontal coordinate information is referenced to the World Geodetic System of 1984 (WGS 84). 


\title{
Geomorphic Classification and Evaluation of Channel Width and Emergent Sandbar Habitat Relations on the Lower Platte River, Nebraska
}

\author{
By Caroline M. Elliott
}

\section{Abstract}

This report presents a summary of geomorphic characteristics extracted from aerial imagery for three broad segments of the Lower Platte River. This report includes a summary of the longitudinal multivariate classification in Elliott and others (2009) and presents a new analysis of total channel width and habitat variables. Three segments on the lower 102.8 miles of the Lower Platte River are addressed in this report: the Loup River to the Elkhorn River (70 miles long), the Elkhorn River to Salt Creek (6.9 miles long), and Salt Creek to the Missouri River (25.9 miles long). The locations of these segments were determined by the locations of tributaries potentially significant to the hydrology or sediment supply of the Lower Platte River.

This report summarizes channel characteristics as mapped from July 2006 aerial imagery including river width, valley width, channel curvature, and in-channel habitat features. In-channel habitat measurements were not made under consistent hydrologic conditions and must be considered general estimates of channel condition in late July 2006. Longitudinal patterns in these features are explored and are summarized in the context of the longitudinal multivariate classification in Elliott and others (2009) for the three Lower Platte River segments. Detailed descriptions of data collection and classification methods are described in Elliott and others (2009). Nesting data for the endangered interior least tern (Sternula antillarum) and threatened piping plover (Charadrius melodus) from 2006 through 2009 are examined within the context of the multivariate classification and Lower Platte River segments.

The widest reaches of the Lower Platte River are located in the segment downstream from the Loup River to the Elkhorn River. This segment also has the widest valley and highest degree of braiding of the three segments and many large vegetated islands. The short segment of river between the Elkhorn River and Salt Creek has a fairly low valley width and high channel sinuosities at larger scales. The segment from Salt Creek to the Missouri River has narrow valleys and generally low channel sinuosity. Tern and plover nest sites from 2006 through 2009 in the multi-scale multivariate classification indicated relative nesting selection of cluster 2 reaches among the four-cluster classification and reaches containing clusters 2,3 , and 6 from the seven-cluster classification. These classes, with the exception of cluster 6 are common downstream from the Elkhorn River.

Trends in total channel width indicated that reaches dominated by dark vegetation (islands) are the widest on the Lower Platte River. Reaches with high percentages of dry sand and dry sand plus light vegetation were the narrowest reaches. This suggests that narrow channel reaches have sufficient transport capacity to maintain sandbars under recent (2006) flow regimes and are likely to be most amenable to maintaining tern and plover habitat in the Lower Platte River. Further investigations into the dynamics of emergent sandbar habitat and the effects of bank stabilization on in-channel habitats will require the collection and analysis of new data, particularly detailed elevation information and an assessment of existing bank stabilization structures.

\section{Introduction}

The Lower Platte River Cumulative Impact Study seeks to examine cumulative effects of past, present, and future changes in the river corridor and their effect on the habitats of the Platte River. There is a particular need to address the potential effects of bank stabilization on physical habitats in the Lower Platte River. Detailed information on bank stabilization is not available for the Lower Platte River and limited information is available on Lower Platte River habitats. This report addresses the information content of channel width variation along the river and inferences about habitat availability for listed bird species.

The lower 103 miles of the Platte River from the Loup River confluence to its mouth have historically been nesting areas for the endangered interior least tern (Sternula antillarum) and threatened piping plover (Charadrius melodus) (Lingle, 1993; Lott, 2006). Although the majority of nesting occurs in sandpits in the floodplain the active 
channel of the river contributes a part of nesting, foraging, and congregation habitats for the Platte River valley population (Lott, 2006; Brown and Jorgenson, 2008, 2009). The riverine habitats these shorebirds utilize for nesting and rearing on the Lower Platte River include sparsely vegetated channel sandbars, sand and gravel beaches on islands, temporary pools on sandbars and islands, and river shorelines (Ziewitz and others, 1992; Lingle, 1993; Kirsch, 1996).

Successful tern and plover nesting has been documented on ephemeral sandbars in the Lower Platte River since the 1800s and monitoring has been systematic since the species were listed in 1985 and 1986 (U.S. Fish and Wildlife Service, 2006; Brown and Jorgenson, 2008, 2009). Tern and plover nesting and habitat use on the Lower Platte River is denser below the junction with the Loup River, a relatively undeveloped sand-bedded tributary with minimally regulated high flows compared to the upstream Central Platte River reaches (Ziewitz and others, 1992; Brown and Jorgenson, 2008).

Present (2010) and anticipated cumulative effects of channel and channel-margin modifications on tern and plover habitat sustainability are not known. This report examines and summarizes the results from the geomorphic classification of Elliott and others (2009) for the Lower Platte River in three reaches downstream from the Loup River. Results may enable federal, state, and local managers and governments to integrate land use planning with regional conservation planning to protect Lower Platte River resources of concern including least tern and piping plover habitat.

\section{Purpose and Scope}

The objective of this report is to summarize the information within the longitudinal multivariate classification in Elliott and others (2009), re-tabulate the data using English units for broad geomorphic segments for the Lower Platte River, and present a new analysis of channel width and habitat variables. The aerial orthophotography analysis of Elliott and others (2009) was re-analyzed to examine the relation between total channel width and the aggregated extent of habitat features. Detailed descriptions of the methods used for data collection and classification are described in Elliott and others (2009).

\section{Least Tern and Piping Plover Habitat}

Interior least terns and piping plovers nest in sandpits in the Platte River valley and emergent sandbar habitat on the Platte River (Kirsch, 1996; Lott, 2006). Platte River nesting locations are bare to sparsely vegetated sandbars with generally less than 25 percent vegetation (Kirsch, 1996). Terns and plovers usually select the highest elevation unvegetated areas of sandbars on the Platte River (Sidle and others, 1992; Ziewitz and others, 1992). On the Central and Lower Platte River, terns and plovers have been documented to nest on sites with a wide active channel and large mid-channel sandbars (Ziewitz and others, 1992). The Platte River provides important foraging and congregation sites for terns and plovers that nest off-river in sandpits in the Platte River floodplain (Lingle, 1993).

\section{Physical Setting and Study Segments}

The Lower Platte River is a wide and generally shallow sand-bedded river with variously vegetated bars and islands. The study area includes three segments of the Lower Platte River in Nebraska from the Loup River junction to the Missouri River confluence (fig. 1, table 1). The segments include: (1) the Loup River to the Elkhorn River (70 miles long), (2) the Elkhorn River to Salt Creek (6.9 miles long), and (3) Salt Creek to the Missouri River (25.9 miles long). These segments were determined by the locations of tributaries considered to be significant to the hydrology or sediment supply of the Lower Platte River.

The Platte River's active channel has experienced a reduction in width and an increase in woody vegetation since the mid-19th century (Williams, 1978; Johnson, 1994, 1997). Channel narrowing of the Central Platte River's active channel from 1865 to 1998 varies from 54 to 87 percent upstream from Grand Island, Nebraska (Murphy and others, 2004). Although the Lower Platte River also followed the same general trend of channel narrowing there were lower rates of channel area reduction and higher rates of bank erosion from 1860 to 2005 in reaches of the Lower Platte River downstream from the Loup and Elkhorn Rivers (Joeckel and Henebry, 2008). Joeckel and Henebry (2008) attribute the lower rates of channel narrowing and higher rates of bank erosion to higher discharges and sediment supply contributed by tributaries (the Loup and Elkhorn Rivers) and the increasing precipitation gradient moving eastward across the state of Nebraska.

The term emergent sandbar habitat specifically refers to higher elevation regions of unvegetated dry sand on bars that remain above the water surface during the tern and plover breeding season. This report does not explicitly address measurements of emergent sandbar habitat as elevations cannot be determined from aerial photography made during periods of fluctuating discharge. In discussing emergent sandbar habitat we refer to dry sand and a braiding channel count index and recognize that these variables are subject to change with fluctuations in discharge. 

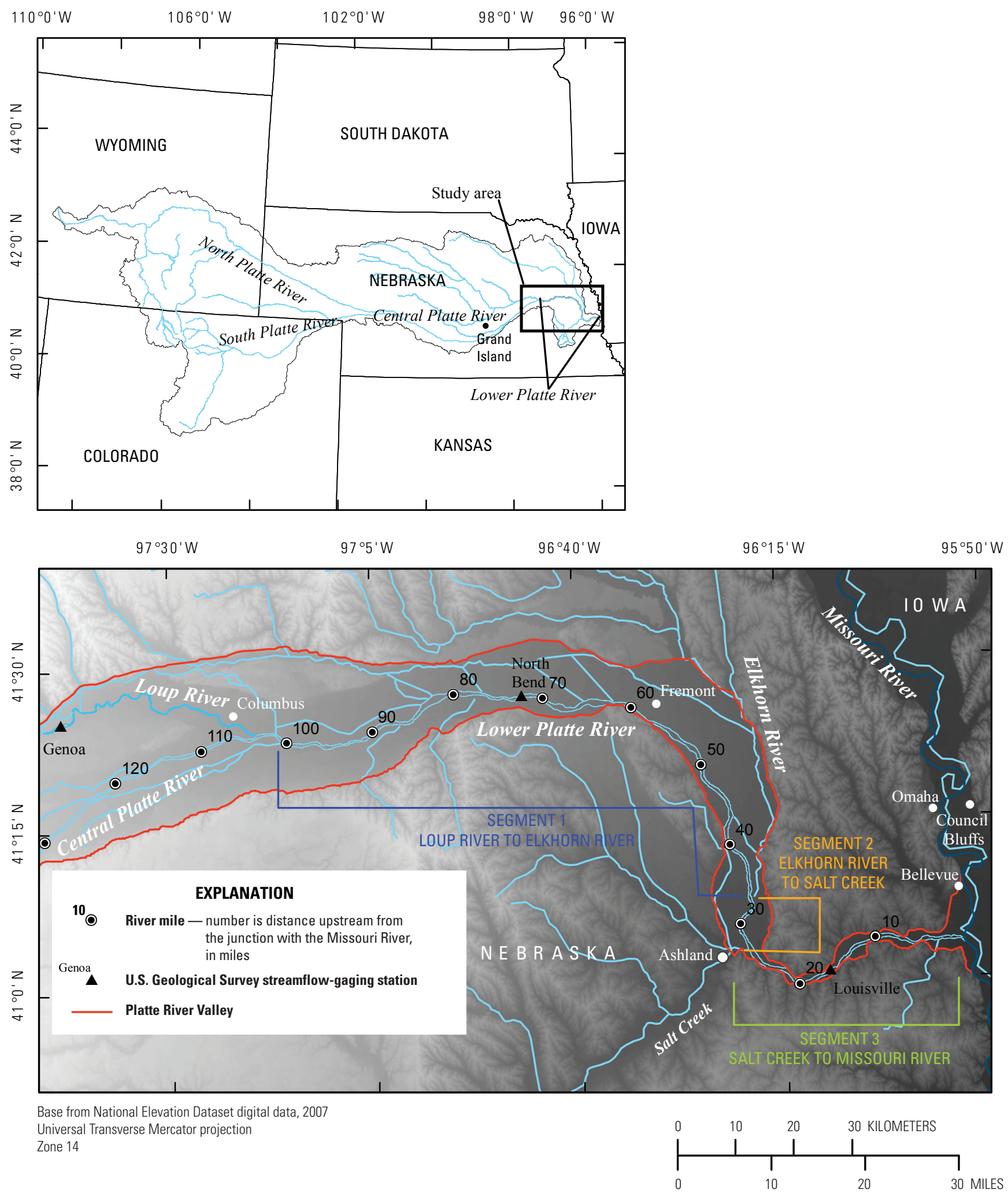

Figure 1. The Platte River Basin and the Lower Platte River study area. 
Table 1. Lower Platte River segments.

\begin{tabular}{cccc}
\hline $\begin{array}{c}\text { Reach } \\
\text { number }\end{array}$ & $\begin{array}{c}\text { Segment } \\
\text { name }\end{array}$ & $\begin{array}{c}\text { Platte River } \\
\text { mile range }\end{array}$ & $\begin{array}{c}\text { Total reach } \\
\text { length, in } \\
\text { miles }\end{array}$ \\
\hline 1 & $\begin{array}{c}\text { Columbus/Loup River } \\
\text { to Elkhorn River }\end{array}$ & 102.8 to 32.8 & 70 \\
2 & $\begin{array}{c}\text { Elkhorn River to } \\
\text { Salt Creek }\end{array}$ & 32.8 to 25.9 & 6.9 \\
3 & $\begin{array}{c}\text { Salt Creek to } \\
\text { Missouri River }\end{array}$ & 25.9 to 0 & 25.9 \\
\hline
\end{tabular}

\section{Hydrology}

The Platte River has an altered flow regime because of irrigation withdrawals, reservoir regulation, and groundwater pumping (Hadley and others, 1987; Randle and Samad, 2003). The Lower Platte River has a reduced frequency of annual high flows from reservoir management and a reduction in average annual flow because of agricultural diversions (Williams, 1978; Simons and Associates Inc., 2000; Randle and Samad, 2003). Under natural conditions, high flows would help to create and maintain sandbar nesting habitat by transporting sediment and scouring vegetation. Historically very low flows probably occurred seasonally during late summer on the Lower Platte River (Hadley and others, 1987; Simons and Associates Inc., 2000). The Lower Platte River also has daily fluctuating discharges because of hydropower peaking which can result in flow fluctuations that make it difficult to acquire aerial photography with a consistent discharge over long segments. Daily fluctuations are illustrated for the Platte River at North Bend, Nebraska (fig. 2).

Stratification of imagery by date was not useful for this analysis because of fluctuation between daily minimum and maximum flows.

The Loup River, Elkhorn River, and Salt Creek are tributaries that enter the Platte River at 102.8, 32.8, and 25.9 miles, respectively, upstream from the mouth of the Platte River at the Missouri River (fig. 1). These tributaries generally retain seasonal flow patterns with flood peaks corresponding to snowmelt in spring and early summer and low flows in the late summer (fig. 2). These tributaries also contribute sediment to the Lower Platte River. The Loup River Power Canal (not shown) near Genoa, Nebraska results in fluctuating discharge downstream because of power generation and enters the Platte River downstream from the Loup River. Differences between the daily minimum and maximum flows at North Bend and Louisville, Nebraska demonstrate the effects of power peaking on the Lower Platte River (fig. 3, table 2).

\section{Platte River Geomorphic Classification}

The Lower Platte River can be classified broadly into segments that are defined by the location of tributaries. These segments, the Loup River to the Elkhorn River, the Elkhorn River to Salt Creek, and Salt Creek to the Missouri River display distinctly different combinations of geomorphic characteristics (fig. 4, table 3).

\section{Approach and Methods}

This report summarizes the results from Elliott and others (2009), re-tabulates the data using English units for three broad geomorphic segments, and presents a new analysis of channel width and habitat variables for the Lower Platte River. Documentation of the methods used in data collection and classification methods are described in Elliott and others (2009). The geomorphic classification data originated from 2006 National Aerial Imagery Program (NAIP) imagery and has been aggregated by Lower Platte River segment for this report. Channel attributes were collected at 0.3-mile (500-meter) address points along the centerline of the Lower Platte River (Elliott and Jacobson, 2006; Elliott and others, 2009). Channel width calculations as defined by Elliott and others (2009) included large vegetated bars located within the high banks of the Lower Platte River and will be referred to in this report as "total channel width". Channel width by river mile was recalculated for this report at river miles starting at 0 at the mouth of the Lower Platte River at the Missouri River. Measures of channel width not including large vegetated bars at each river mile and will be referred to as "active channel width".

\section{Channel and Valley Width}

Valley width and channel width measurements were made from hand-digitized polyline layers from 2006 NAIP imagery. The edge of the valley was identified at a 1:5,000 scale using the 2006 NAIP imagery as well as topographic and geologic maps and a 30-meter Digital Elevation Model from the National Elevation Dataset (Gesch and others, 2002; Gesch, 2007). The valley edge was defined by steep breaks in slope indicative of the bedrock valley of the Platte River and includes terraces within the larger bedrock valley. The river banks were digitized on the computer screen at a 1:5,000 scale to include the channel defined by steep slope breaks on banks, the presence of open water, and geomorphic features indicative of frequent sediment transport. Defining the channel by the edge of the banks, rather than the edge of water allows for comparison between aerial photographs of 

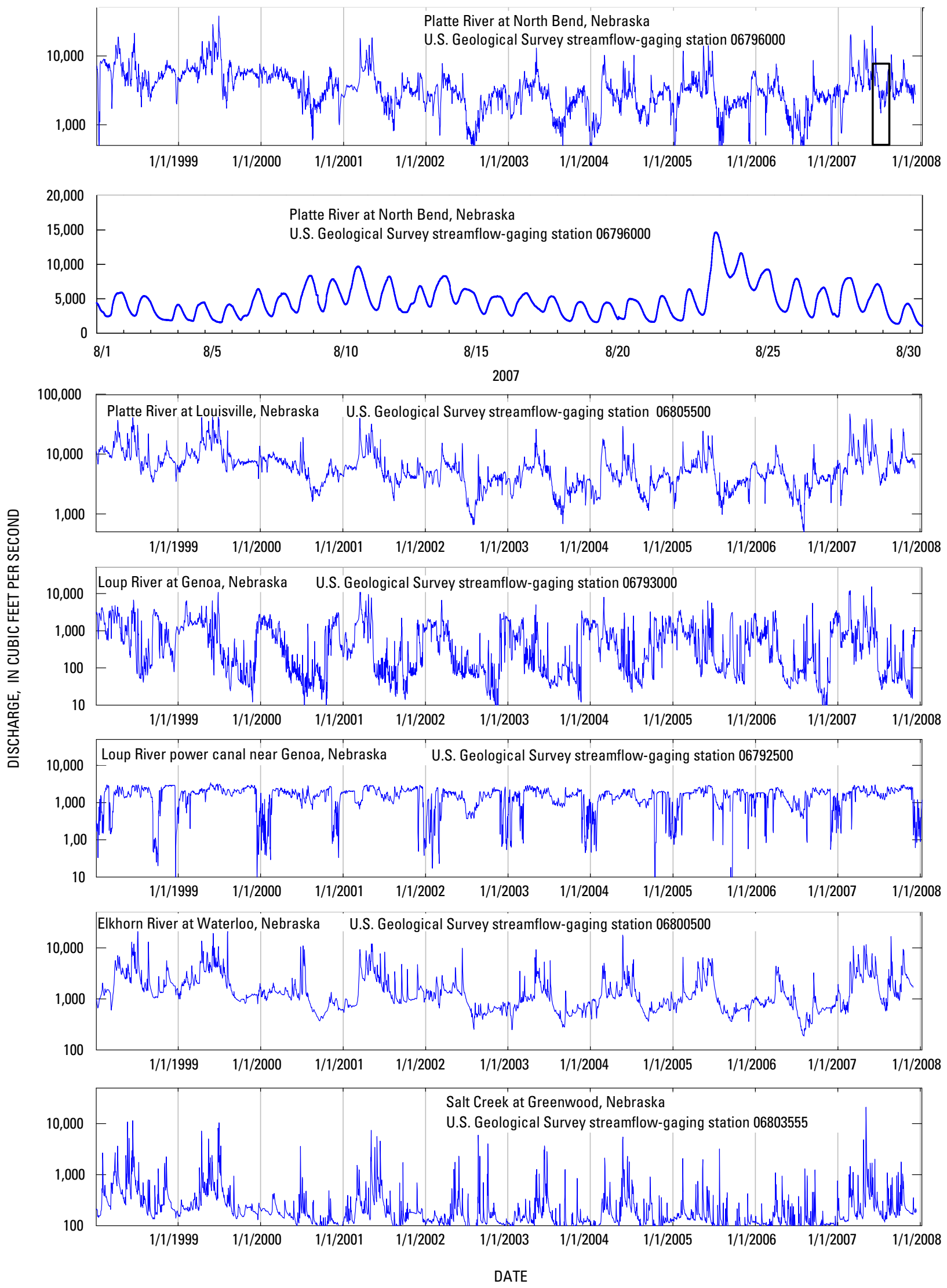

Figure 2. Discharge for the Lower Platte River and tributaries. 


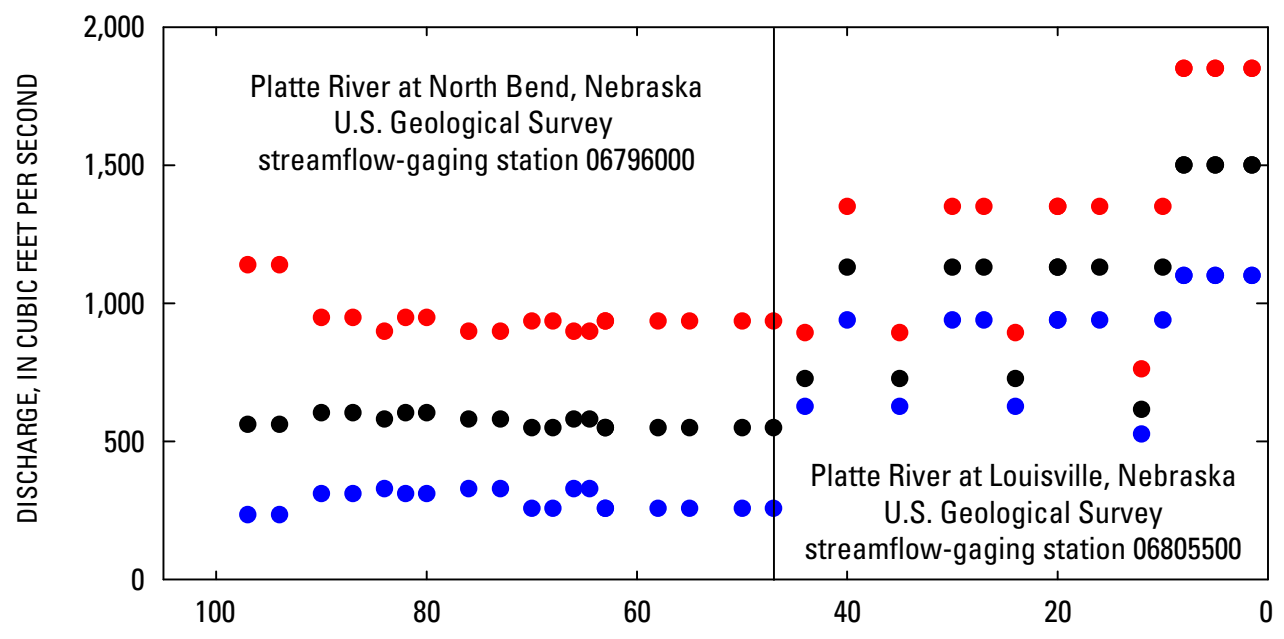

\section{EXPLANATION}

- Maximum daily discharge for aerial photographs

- Minimum daily discharge for aerial photographs

- Average daily discharge for aerial photographs

DISTANCE UPSTREAM FROM MISSOURI RIVER JUNCTION, IN MILES

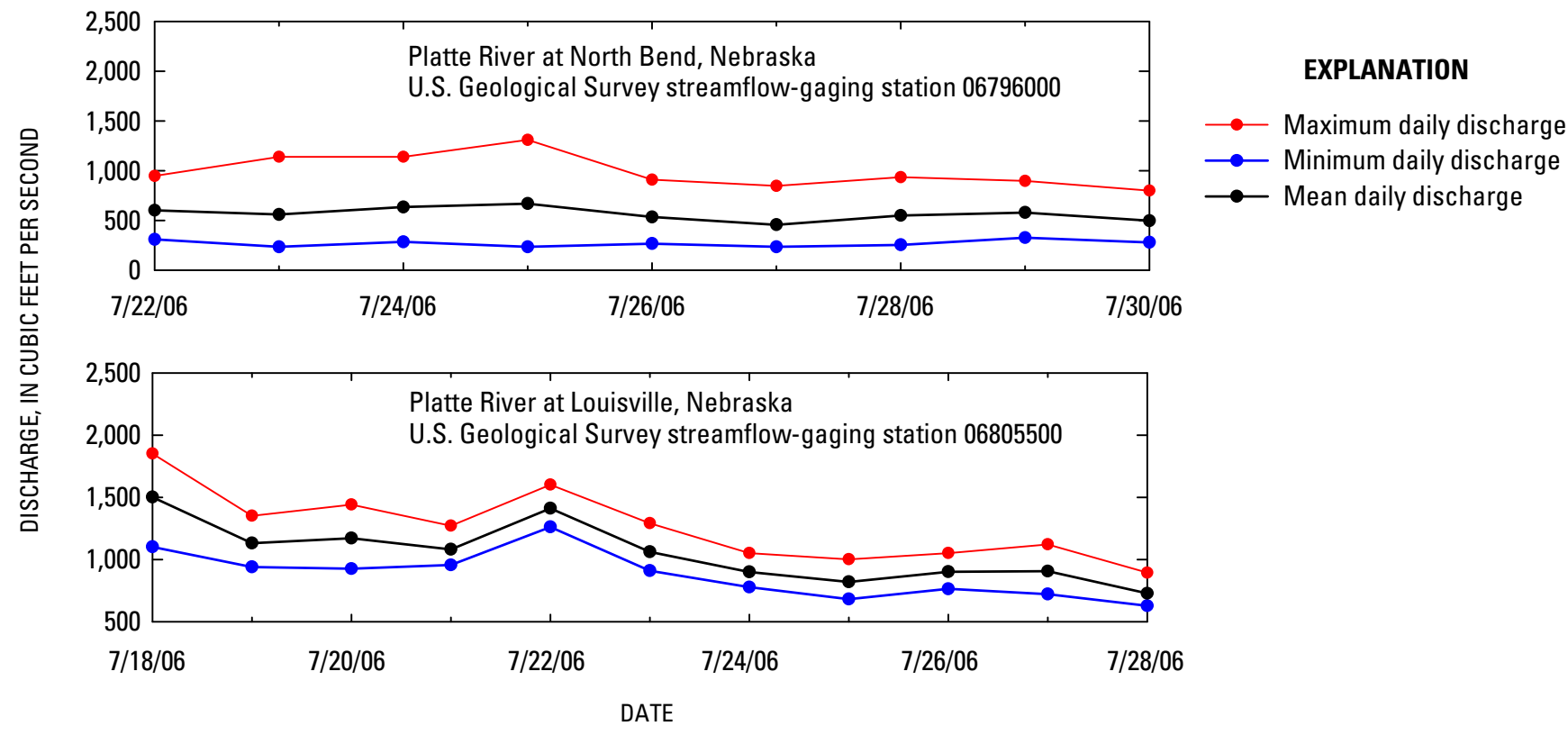

Figure 3. Locations and discharges for the Lower Platte River for 2006 National Aerial Imagery Program photographs used in this study at the North Bend and Louisville streamflow gages on the Platte River, Nebraska. 
Table 2. Dates and river discharges for 2006 digital photography.

[NAIP, National Aerial Imagery Program; river mile, refers to the distance upstream from the Platte River's junction with the Missouri River; $\mathrm{ft}^{3} / \mathrm{s}$, cubic feet per second; Platte River streamflow-gaging station and identification numbers: Grand Island, Nebraska, 06770500; North Bend, Nebraska, 06796000; and Louisville, Nebraska, 06805500]

\begin{tabular}{|c|c|c|c|c|c|c|c|}
\hline $\begin{array}{c}2006 \text { NAIP } \\
\text { quarter quadrangle }\end{array}$ & Image date & $\begin{array}{l}\text { Beginning } \\
\text { river mile }\end{array}$ & $\begin{array}{l}\text { Ending } \\
\text { river mile }\end{array}$ & $\begin{array}{l}\text { Maximum dis- } \\
\text { charge }\left(\mathrm{ft}^{3} / \mathrm{s}\right)\end{array}$ & $\begin{array}{l}\text { Minimum dis- } \\
\text { charge (ft } / 3 / s)\end{array}$ & $\begin{array}{c}\text { Mean dis- } \\
\text { charge (ft }\left(\mathrm{t}^{3} / \mathrm{s}\right)\end{array}$ & $\begin{array}{l}\text { Streamflow } \\
\text { gage }\end{array}$ \\
\hline Columbus SE & $7 / 26 / 2006$ & 103 & 99.5 & 0 & 0 & 0 & Grand Islanc \\
\hline Richland SW & $7 / 23 / 2006$ & 99.5 & 96 & 1,140 & 235 & 561 & North Bend \\
\hline Richland SE & $7 / 23 / 2006$ & 96 & 92.5 & 1,140 & 235 & 561 & North Bend \\
\hline Schuyler SW & $7 / 22 / 2006$ & 92.5 & 88.5 & 949 & 310 & 603 & North Bend \\
\hline Schuyler SE & $7 / 22 / 2006$ & 88.5 & 85.5 & 949 & 310 & 603 & North Bend \\
\hline Rogers SW & $7 / 29 / 2006$ & 85.5 & 83.5 & 898 & 328 & 581 & North Bend \\
\hline Rogers NW & $7 / 22 / 2006$ & 83.5 & 81.5 & 949 & 310 & 603 & North Bend \\
\hline Rogers NE & $7 / 22 / 2006$ & 81.5 & 78 & 949 & 310 & 603 & North Bend \\
\hline North Bend NW & $7 / 29 / 2006$ & 78 & 74.5 & 898 & 328 & 581 & North Bend \\
\hline North Bend NE & $7 / 29 / 2006$ & 74.5 & 71 & 898 & 328 & 581 & North Bend \\
\hline Malmo NW NW & $7 / 28 / 2006$ & 71 & 69 & 936 & 257 & 550 & North Bend \\
\hline Malmo NW SW & $7 / 28 / 2006$ & 69 & 67.5 & 936 & 257 & 550 & North Bend \\
\hline Malmo NW SE & $7 / 29 / 2006$ & 67.5 & 65 & 898 & 328 & 581 & North Bend \\
\hline Malmo NW NE & $7 / 29 / 2006$ & 65.5 & 64 & 898 & 328 & 581 & North Bend \\
\hline Fremont West NW & $7 / 28 / 2006$ & 64 & 61 & 936 & 257 & 550 & North Bend \\
\hline Fremont West SW & $7 / 28 / 2006$ & 64 & 61 & 936 & 257 & 550 & North Bend \\
\hline Fremont West SE & $7 / 28 / 2006$ & 61 & 57 & 936 & 257 & 550 & North Bend \\
\hline Fremont East SW & $7 / 28 / 2006$ & 57 & 53 & 936 & 257 & 550 & North Bend \\
\hline Leshara NE & $7 / 28 / 2006$ & 53 & 48 & 936 & 257 & 550 & North Bend \\
\hline Leshara SE & $7 / 28 / 2006$ & 48 & 46 & 936 & 257 & 550 & North Bend \\
\hline Valley SW & $7 / 28 / 2006$ & 46 & 43 & 893 & 626 & 727 & Louisville \\
\hline Wann NW & $7 / 19 / 2006$ & 43 & 37.5 & 1,350 & 939 & 1,130 & Louisville \\
\hline Wann SW & $7 / 28 / 2006$ & 37.5 & 33 & 893 & 626 & 727 & Louisville \\
\hline Ashland East NW & $7 / 19 / 2006$ & 33 & 28 & 1,350 & 939 & 1,130 & Louisville \\
\hline Ashland East SW & $7 / 19 / 2006$ & 28 & 26 & 1,350 & 939 & 1,130 & Louisville \\
\hline Ashland East SE & $7 / 28 / 2006$ & 26 & 22 & 893 & 626 & 727 & Louisville \\
\hline Springfield SW & $7 / 19 / 2006$ & 22 & 18 & 1,350 & 939 & 1,130 & Louisville \\
\hline Manley NW & $7 / 19 / 2006$ & 21 & 19 & 1,350 & 939 & 1,130 & Louisville \\
\hline Springfield SE & $7 / 19 / 2006$ & 18 & 14 & 1,350 & 939 & 1,130 & Louisville \\
\hline Cedar CreekSW & $7 / 29 / 2006$ & 14 & 10 & 762 & 526 & 615 & Louisville \\
\hline Cedar Creek NW & $7 / 19 / 2006$ & 10.5 & 10 & 1,350 & 939 & 1,130 & Louisville \\
\hline Cedar Creek NE & $7 / 18 / 2006$ & 10 & 6.5 & 1,850 & 1,100 & 1,500 & Louisville \\
\hline Cedar Creek SE & $7 / 18 / 2006$ & 10 & 6.5 & 1,850 & 1,100 & 1,500 & Louisville \\
\hline Plattsmouth NW & $7 / 18 / 2006$ & 6.5 & 3 & 1,850 & 1,100 & 1,500 & Louisville \\
\hline Plattsmouth SW & $7 / 18 / 2006$ & 6.5 & 3 & 1,850 & 1,100 & 1,500 & Louisville \\
\hline Plattsmouth NE & $7 / 18 / 2006$ & 3 & 0 & 1,850 & 1,100 & 1,500 & Louisville \\
\hline Plattsmouth SE & $7 / 18 / 2006$ & 3 & 0 & 1,850 & 1,100 & 1,500 & Louisville \\
\hline
\end{tabular}



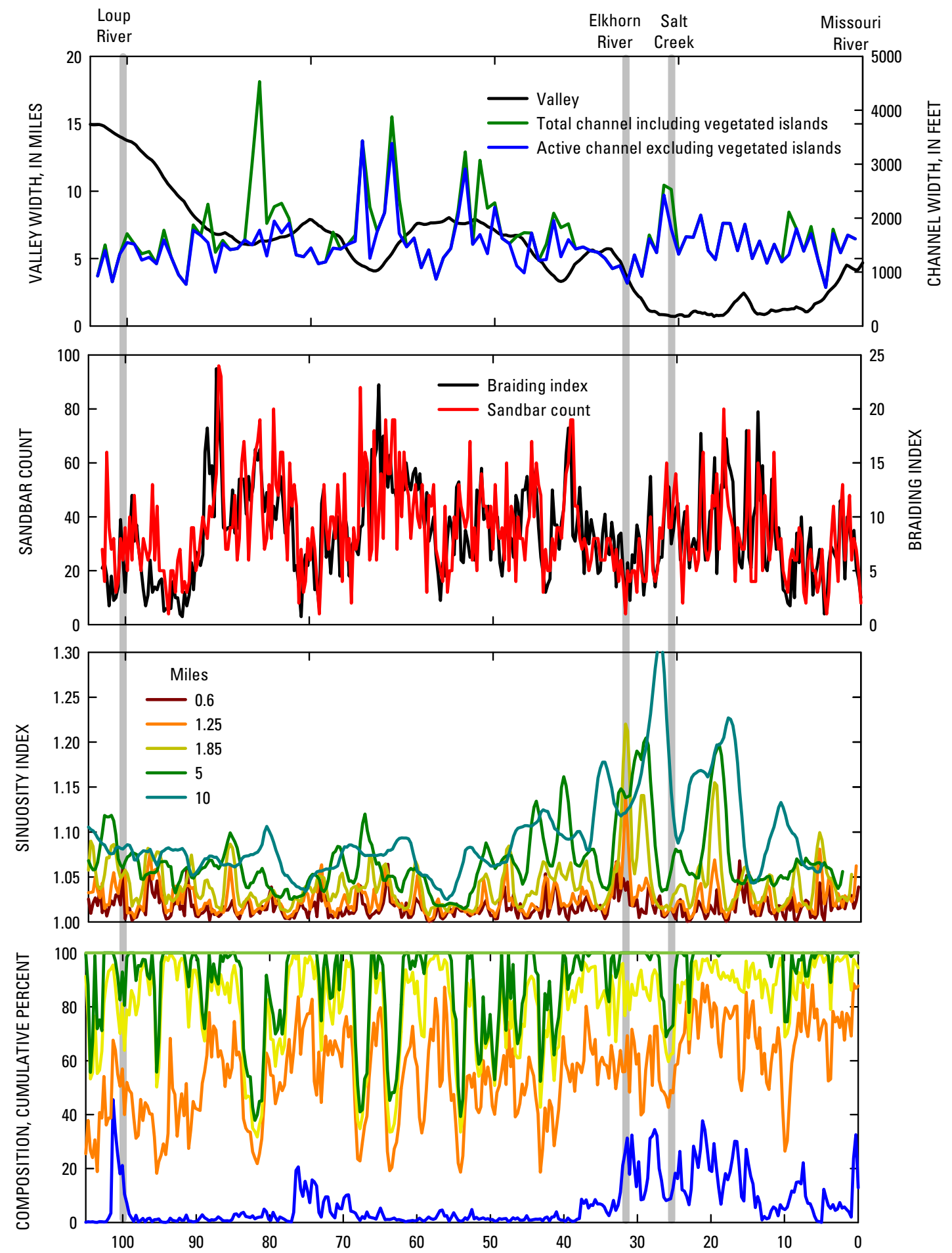

EXPLANATION

DISTANCE UPSTREAM OF MOUTH, IN MILES

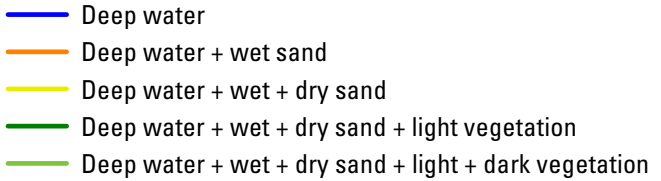

Figure 4. Lower Platte River geomorphic characteristics including valley width, channel width, sinuosity, sandbar count, channel count index, and percent of channel composition. 
Table 3. Lower Platte River geomorphic attributes summarized by hydrologic segment.

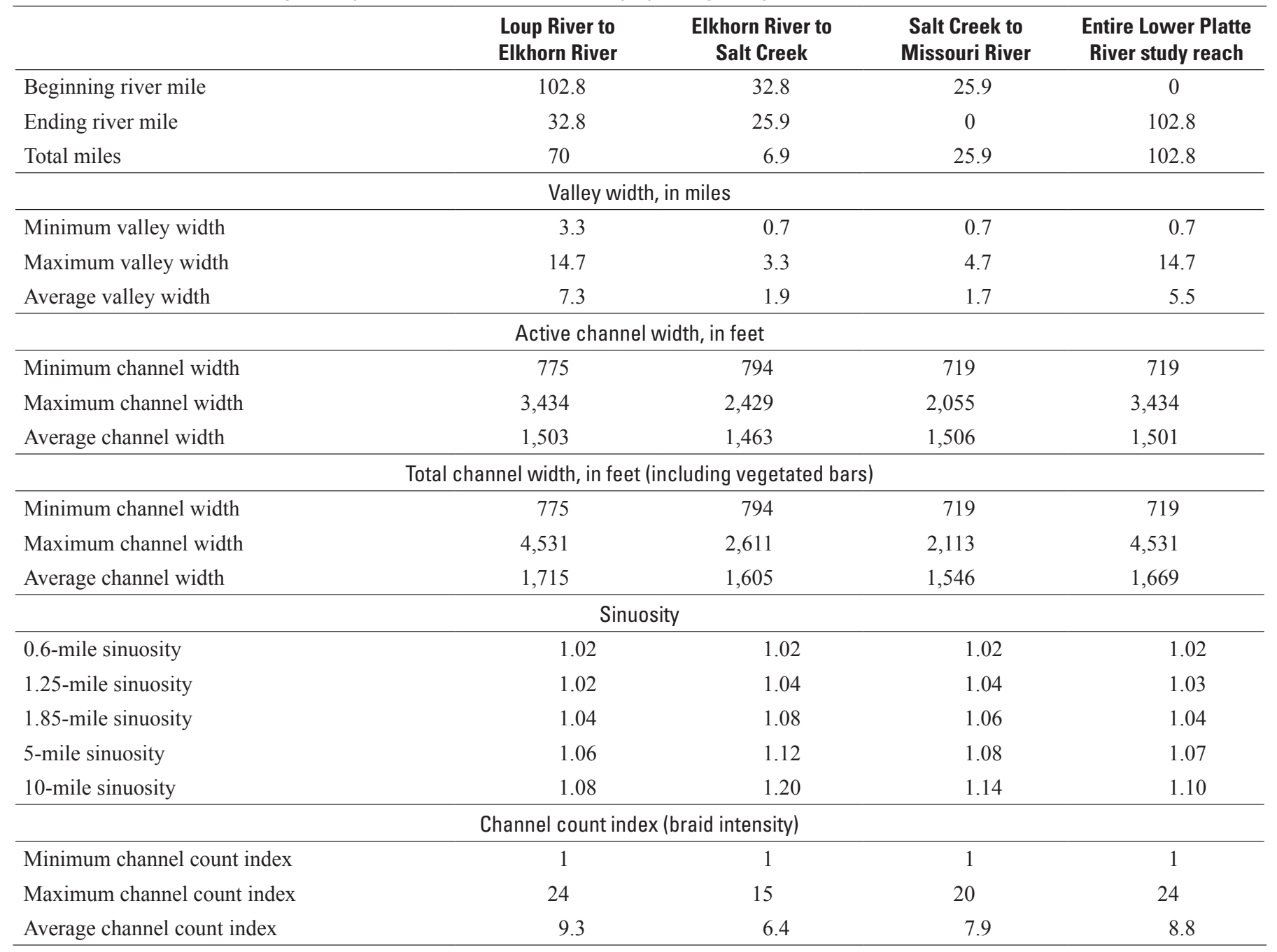

varying discharge. Channel width calculations as defined by Elliott and others (2009) included large vegetated bars within the high banks of the channel and will be referred to as total channel width. For this report, additional measurements of active channel width were made of transects at each river mile. The width of large vegetated bars that fell on the width transects was subtracted from the total high bank to high bank channel width, therefore producing measures of channel width including and excluding vegetated bars (fig. 4A).

Valley width varies from 0.7 to 14.7 miles on the Lower Platte River with the widest reaches occurring just downstream from the confluence with the Loup River (fig. 4A, table 3). A narrow reach that begins between the Elkhorn River and Salt Creek and extends to the Missouri River has been named the "Eastern Platte River Gorge" by Joeckel and Henebry, 2008. Valley widths as well as variation in valley widths are lower in the two segments downstream from the Elkhorn River and Salt Creek (figs. 4A, 5A).

Active channel width (not including vegetated bars) varies between 719 and 3,434 feet on the Lower Platte River with the widest reaches occurring between the Loup River and Elkhorn River (figs. 4A, 5B, and table 3). When total channel width is measured from high bank to high bank (including large vegetated islands) the range in channel width is 719 to 4,531 feet. The widest reaches in the segment from the Loup River to the Elkhorn River contain large vegetated islands. Although there is considerable variation in channel width between the upstream and downstream reaches mean active channel width in all three reaches is similar, around 1,500 feet (fig. $5 B$ ). Mean width does not change much when vegetated islands are included in the measurement (fig. $5 C$ ). 


\section{Sinuosity}

Channel sinuosity is often measured by dividing the distance between points along a thalweg by the straight-line distance between the points. For the Lower Platte River, braiding made it difficult to determine the thalweg and a modified sinuosity index was measured as distance along the channel centerline divided by the straight-line distance and represents the sinuosity of the channel (Elliott and others, 2009). Sinuosity varies with scale and was calculated at every 0.3-mile (500 meter) address point for each 0.6-, 1.25-, 1.85-, 5-, and 10-mile length of channel (fig. 4C).

Sinuosity relates to channel curvature, flow separation, and hydraulic diversity (Barbour and others, 1999). Sinuosity on the Lower Platte River is generally low and increases with scale from 1.02 to as much as 1.20 (figs. $4 C, 5 D$, and $5 F$ ). Sinuosity is lowest at the 0.6 -mile scale in all reaches and highest at the 10-mile scale (table 3). Sinuosity is generally higher at scales greater than the 1.25 -mile scale, particularly in reaches of river where the valley orientation changes as in the segment downstream from the Elkhorn River (figs. 1, 4C).

\section{In-Channel Habitat Features}

In-channel habitat types were mapped by Elliott and others (2009) using automated image classification procedures. This analysis used the same 2006 NAIP imagery used for the channel width measurements. The entire channel was classified using training samples as deep water, dry sand, wet sand, light-colored vegetation, and dark-colored vegetation (fig. 6). These classes compared well with those produced for a manual classification of a smaller area within the Lower Platte River (fig. 6). For the multivariate channel classification, the entire channel was divided into 0.3 -mile long (500-meter) address polygons and habitat features were expressed as percent channel within that reach. Because of the unknown timing of flight paths throughout a period from July 18 to July 29, 2006 and daily fluctuations in discharge from hydropower generation, habitat measurements could not be matched to discharges (fig. 3, table 2). Differences in the minimum and maximum daily flows at North Bend, Nebraska were between 570 and 905 cubic feet per second $\left(\mathrm{ft}^{3} / \mathrm{s}\right)$ and between 236 and $750 \mathrm{ft}^{3} / \mathrm{s}$ at Louisville, Nebraska. Because the 2006 NAIP imagery is attributed with photo date by quarter-quadrangle, but not by time of day, it is not possible to determine discharge precisely at the time of photography. In-channel habitat measurements were not made under consistent hydrologic conditions and must be considered as general estimates of channel condition in late July 2006. Channel features such as dark vegetation, light vegetation, and dry sand appear to be relatively less sensitive than deep water and wet sand to changes in discharge through a hydropeaking cycle. Percent deep water and wet sand are channel characteristics that appear to be sensitive to discharge through a hydropeaking cycle. Aggregating habitat features for broad river segments also may dampen some of the variation in habitats because of discharge fluctuations.

Reaches with a high percent of dark vegetation, which can be interpreted primarily as high-elevation forested land on islands in the channel, occur most frequently between the Loup River and Elkhorn River (figs. 4D, 7A). Downstream from the Elkhorn River dark vegetation on average makes up less than 5 percent of the channel between the high banks (figs. $4 D, 7 A$ ). Light vegetation makes up a higher percentage of the channel in the segments upstream from Salt Creek (figs. $4 D, 7 B$ ). Dry sand occurs as similar percentages of the channel in the segments upstream from Salt Creek with lower mean percentages of the channel downstream from Salt Creek (figs. 4D, 7C). The light vegetation class includes surfaces with vegetation that may have colonized potential sandy nesting habitat and that may be susceptible to scour by high flows or may be amenable to removal by management actions. The light vegetation class was added to dry sand to capture this potential. This aggregated class occurs in higher proportions in the reaches upstream from Salt Creek but makes up between 20 to 40 percent of the channel on average in all three reaches (fig. 7D). Percent deep water and wet sand per segment are included in the analysis but are classes that are likely to be sensitive to fluctuations in flow embedded in the dataset (figs. $4 D, 7 E$, and $7 F$ ).

\section{Braiding}

Braiding intensity was measured by a channel count index calculated by Elliott and others (2009) by counting the number of channels created when the wet sand and deep water classes from the 2006 imagery were combined. Braiding intensity has been demonstrated as sensitive to changes in flow stage and ideally should be measured at several flow stages or at an index discharge (Egozi and Ashmore, 2008) which was not possible with existing Lower Platte River datasets. Channel count indices of braiding are not sensitive to channel sinuosity and orientation and are less sensitive to changes in discharge than bar indices or measures of total channel length (Egozi and Ashmore, 2008).

Braiding intensity measured from image classification of the 2006 NAIP photography was variable on the Lower Platte River with between 1 to 24 channels and an average of 8.8 channels (fig. $4 B$, table 3 ). The segment between the Loup and Elkhorn Rivers has the highest braid intensity on average (fig. $5 F$, table 3). Braiding intensity is sensitive to discharge and may be biased along the river because of fluctuating flow in the 2006 NAIP dataset. 

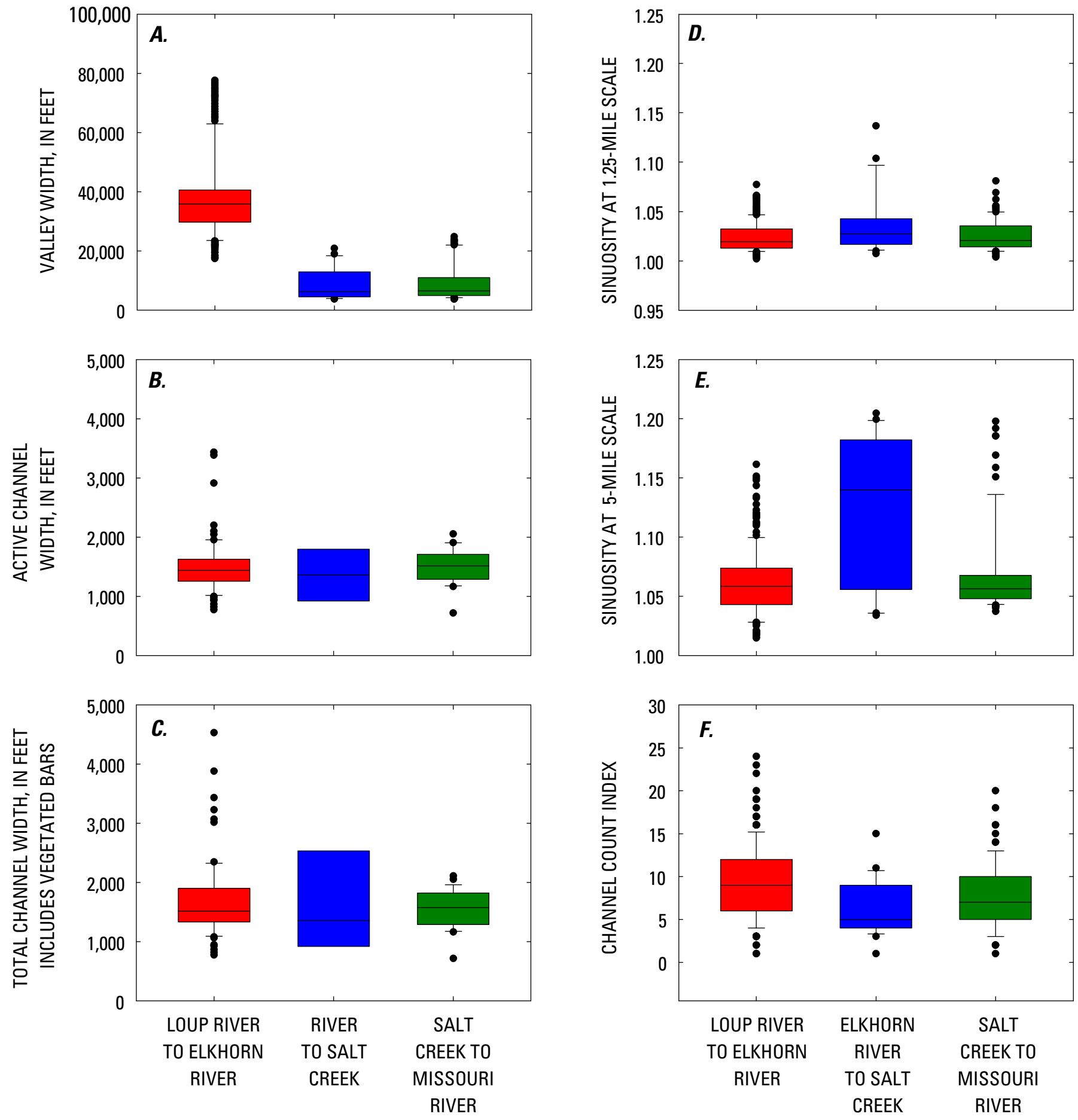

Figure 5. Box and whisker plots of Lower Platte River geomorphic characteristics summarized by segment. 

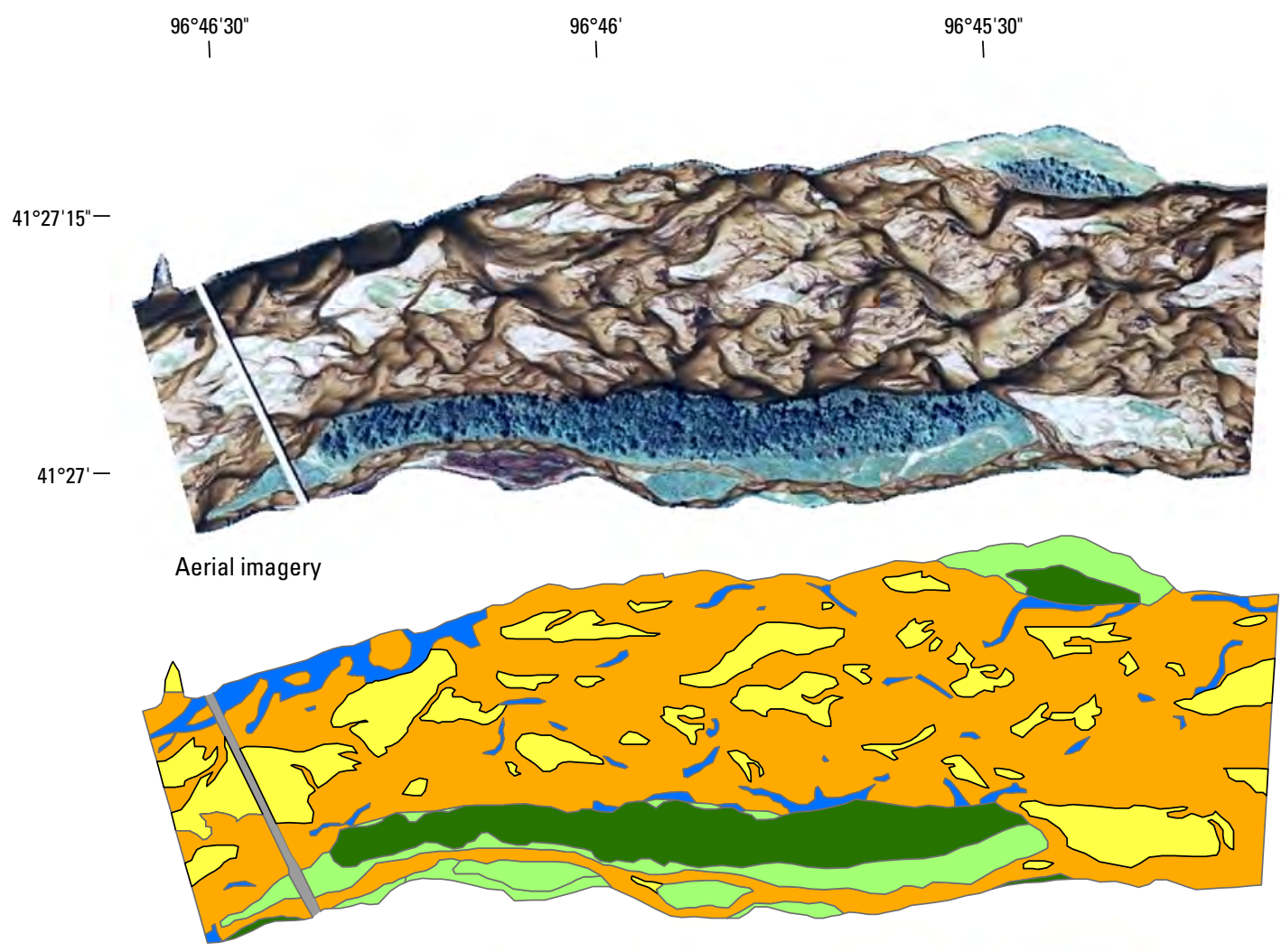

Manual classification

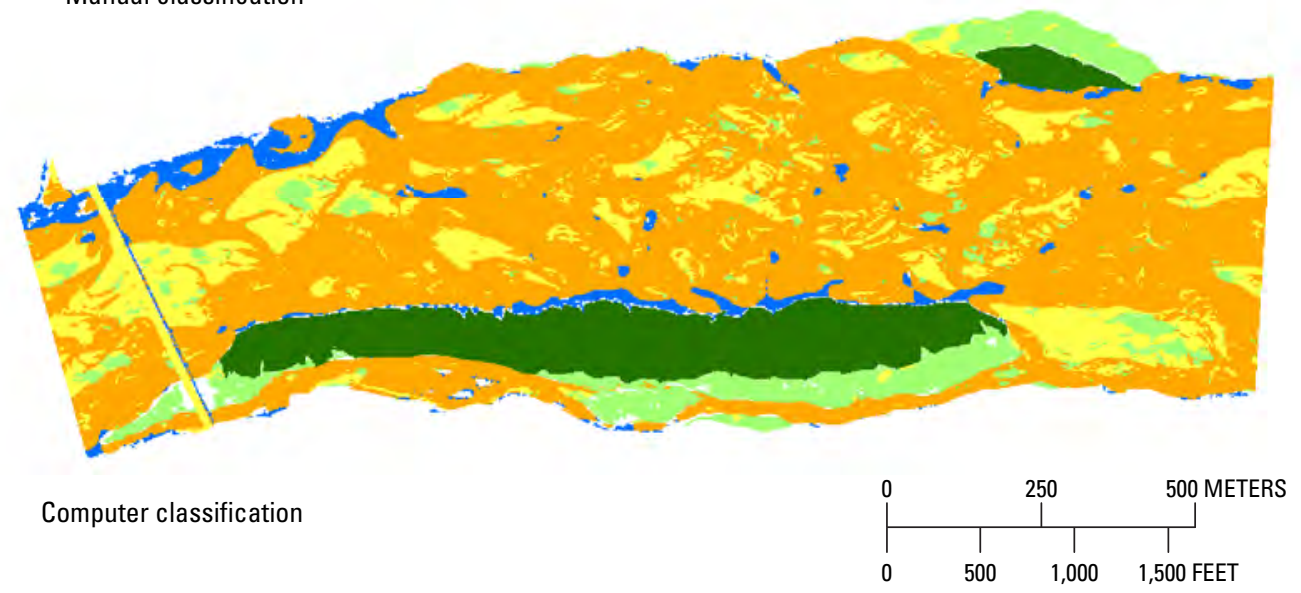

Base from U.S. Department of Agriculture digital data, 2006 National Aerial Imagery Program

Universal Transverse Mercator projection

Zone 14

\section{EXPLANATION}

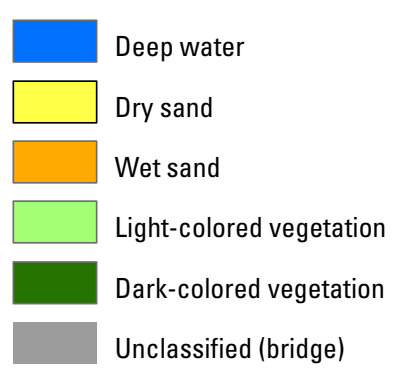

Figure 6. Comparison of National Aerial Imagery Program (NAIP) photography, manual classification, and computerized classification for a 1.25-mile representative reach of the Lower Platte River. 

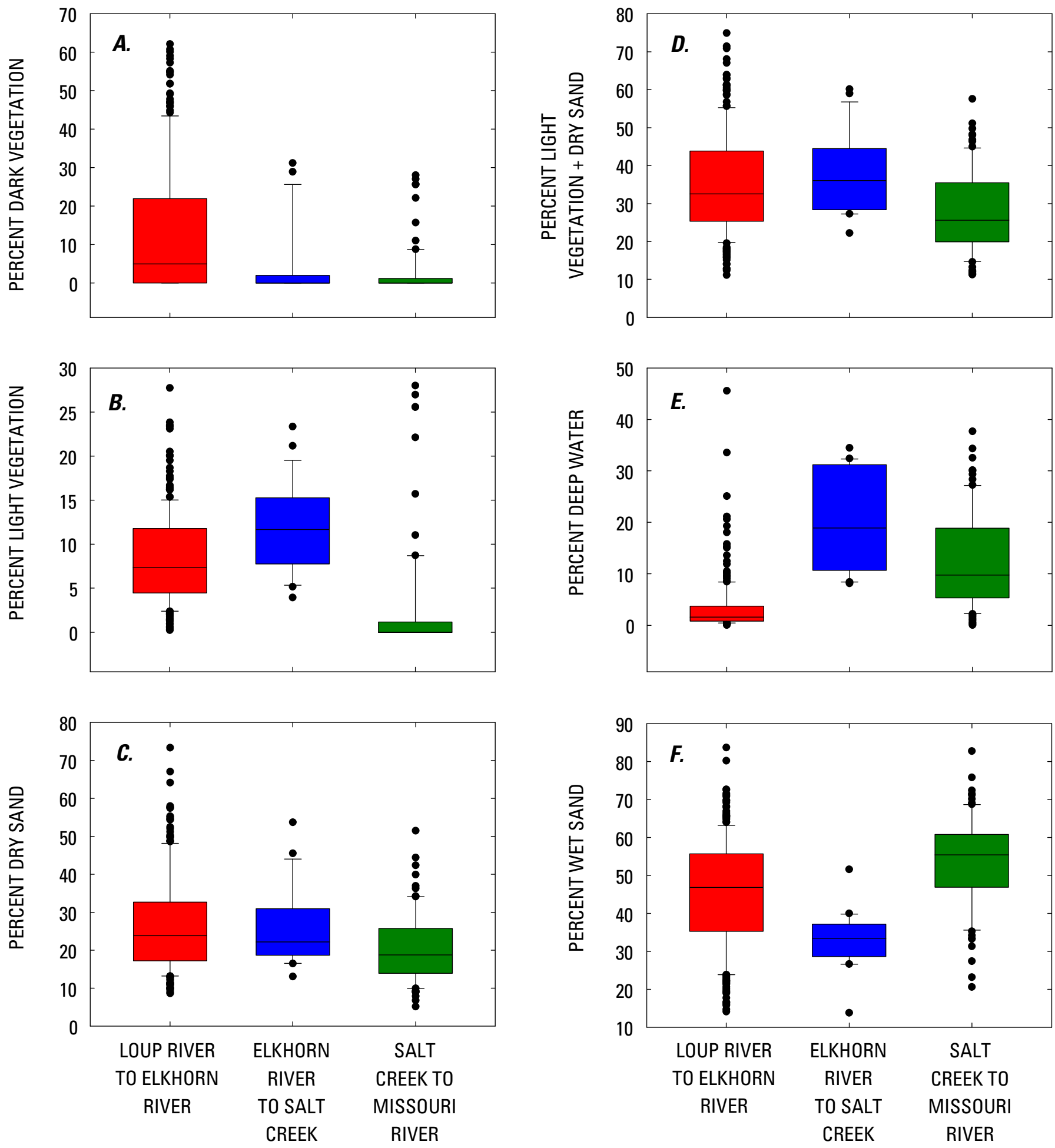

Figure 7. Box and whisker plots of percent of channel type from supervised imagery classification by segment for the Lower Platte River. 


\section{Multivariate Classification}

Within the Lower Platte River multivariate statistical techniques were used to determine the classification of reaches based on clustering of geomorphic features (Elliott and others, 2009). Four relatively independent variables that are not discharge dependant were chosen for the classification. These variables were valley width, channel width, 1.25 -mile sinuosity, and 5-mile sinuosity. Two scales of classification were determined, a four-cluster and seven-cluster classification (fig. 8, table 4). Patterns of cluster occurrence were analyzed within the hydrologic segments defined by major tributaries.

The segment from the Loup River to the Elkhorn River is dominated by cluster 4 of the four-cluster classification (fig. 8, table 5). Cluster 4 is characterized by an intermediate valley width, low-to medium sinuosity, and high channel widths. This segment primarily is made up of reaches classified as clusters 4,5 , and 6 of the seven-cluster classification (fig. 8, table 5).

The short segment between the Elkhorn River and Salt Creek consists of clusters 2 and 3 from the four- and sevencluster classifications with 36.4 and 63.6 percent of the reaches respectively (fig. 8, table 5). These clusters occur in narrow valleys and include reaches with low and high sinuosity.

The Lower Platte River hydrologic segment from Salt Creek to the Missouri River is dominated by cluster 2 of the four-cluster and cluster 2 of the seven-cluster classification (fig. 8, table 5). Cluster 2 reaches have narrow valleys and generally low sinuosities in the four-cluster and seven-cluster classifications.

\section{Tern and Plover Nesting}

There were a total of 265 tern and plover nests mapped on the Lower Platte River in the 2006, 2007, 2008, and 2009 nesting seasons (Joel Jorgenson, unpub. data. Nebraska Game and Parks Commission, 2009) (Brown and Jorgenson, 2008, 2009). Counting all nests from all years, there were 1.4 nests on average per mile in the Lower Platte River (table 6). There were fewer than average nests, 0.9 per mile, located in the segment between the Loup and Elkhorn Rivers. There were 2.8 nests per mile on average in the segment between the Elkhorn River and Salt Creek. The segment below Salt Creek had 2.4 nests per mile, a higher than average number than the Lower Platte River as a whole.

Tern and plover nesting activity was difficult to link directly to the Platte River in-channel habitat assessment from 2006 NAIP imagery because the Platte River is a dynamic environment and high flows, particularly in late May and June of 2008, submerged the channel, deposited and scoured sediment, and changed the locations and elevations of some habitat bars (Brown and Jorgenson, 2009). The reach classification scheme of Elliott and others (2009), however, is based on geomorphically stable variables (channel width, valley width, and sinuosity) that are not as sensitive to discharge variation and changes in the locations of individual bars. Although in-channel habitat features may be temporally variable within the geomorphically defined clusters, it is expected that the clusters define channel reaches that will, on average with time, tend to have suites of similar habitats.

All the nests from 2006 through 2008 were assessed using Ivlev's selectivity coefficients to quantify nesting selection for specific reaches within the classification (Manly and others, 2002; Elliott and others, 2009). Selectivity coefficients were calculated as:

$$
E_{i}=\left(o_{i}-p_{i}\right) /\left(o_{i}+p_{i}\right)
$$

where $E_{i}$ is the selectivity coefficient for resource unit $i$ (from-1 to +1 ), $o_{i}$ is the sampled proportion of reaches with nests, and $p_{i}$ is the sampled proportion of available reaches. Values of selectivity coefficient near zero indicate habitat is used in proportion to its availability and positive coefficient values indicate habitat selection, whereas negative coefficient values indicate avoidance. Nesting coefficients do not indicate a probability of nesting in a reach, but they do document the relative strength of selection among a range of reaches.

Cluster 2 of the four-cluster classification was linked to tern and plover nesting, with a positive selectivity coefficient (Elliott and others, 2009). This reach makes up 36.4 percent of the Elkhorn River to Salt Creek segment and 77.1 percent of the Salt Creek to Missouri River segment of the Lower Platte River (table 5). Clusters 2, 3, and 6 had positive selectivity coefficients in the seven-cluster classification (Elliott and others, 2009). Cluster 2 primarily occurs downstream from the Elkhorn River and makes up 36.4 percent of the reaches from there to upstream from Salt Creek and 74.7 percent of the reaches downstream from Salt Creek. Cluster 3 primarily occurs between the Elkhorn River and Salt Creek, making up 63.6 percent of the reaches in this segment. Cluster 6 makes up 20.7 percent of the reaches in the segment between the Loup River and Elkhorn River.

\section{Channel Width and Habitat}

Total channel width (calculated including vegetated bars) and habitat measurements from Elliott and others (2009) were analyzed to develop relations between channel width and habitat features similar to those developed for the Missouri River.

For this analysis the address polygon reaches were classified by dominant habitat type (greater than or equal to 50 percent of the channel) and plotted as cumulative distributions of channel width (fig. 9). The 0.3-mile (500-meter) address polygon reaches were classed with their dominant habitat type by dominant percent area and assigned the width at the associated address location. The reaches were classified as dominant in dry sand, wet sand, or dark vegetation. Light vegetation and deep water did not occur in quantities equal to or greater than 50 percent of the channel and were therefore not included in this analysis; however, 

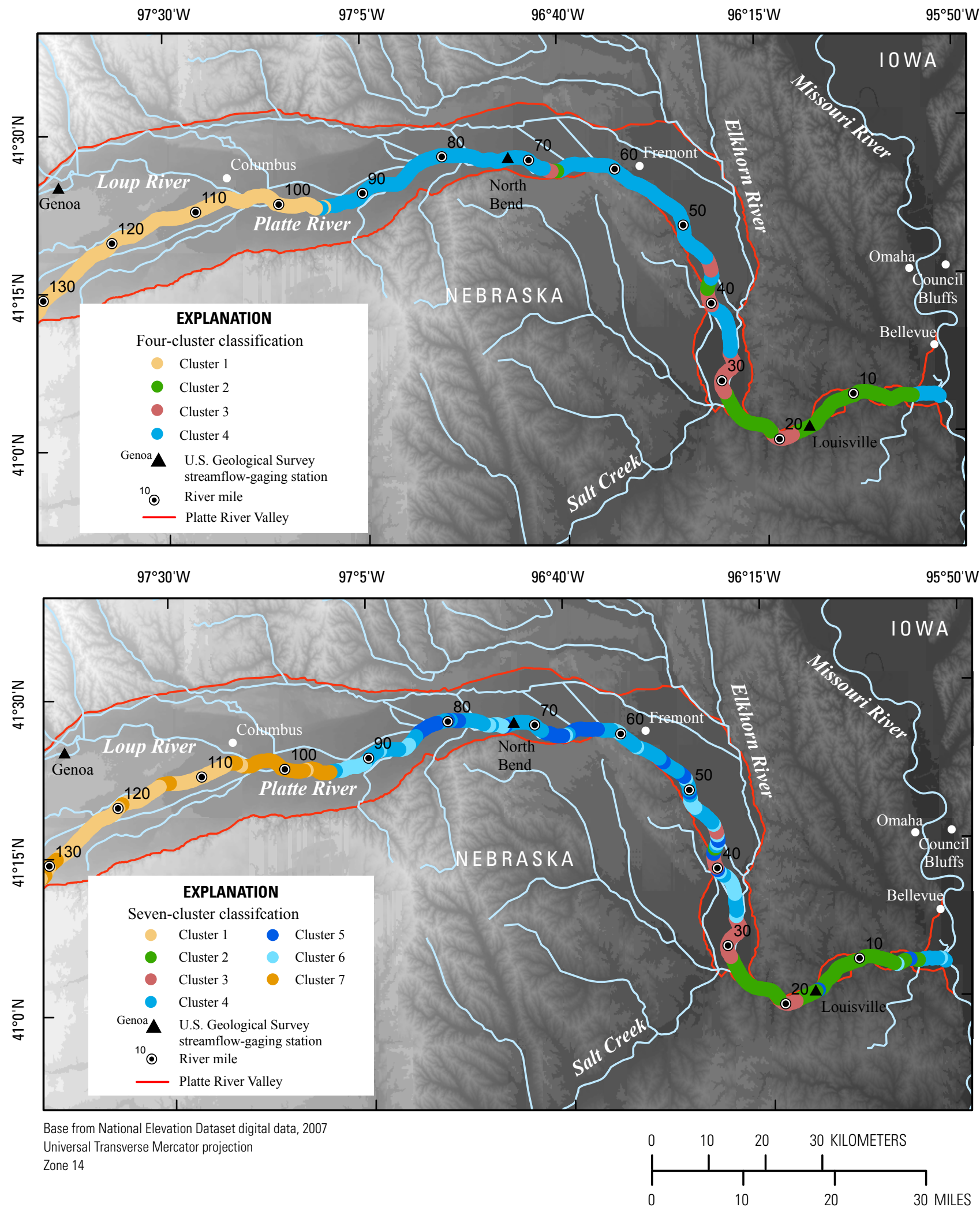

Figure 8. Examples of four- and seven-cluster classifications on the Lower Platte River. 


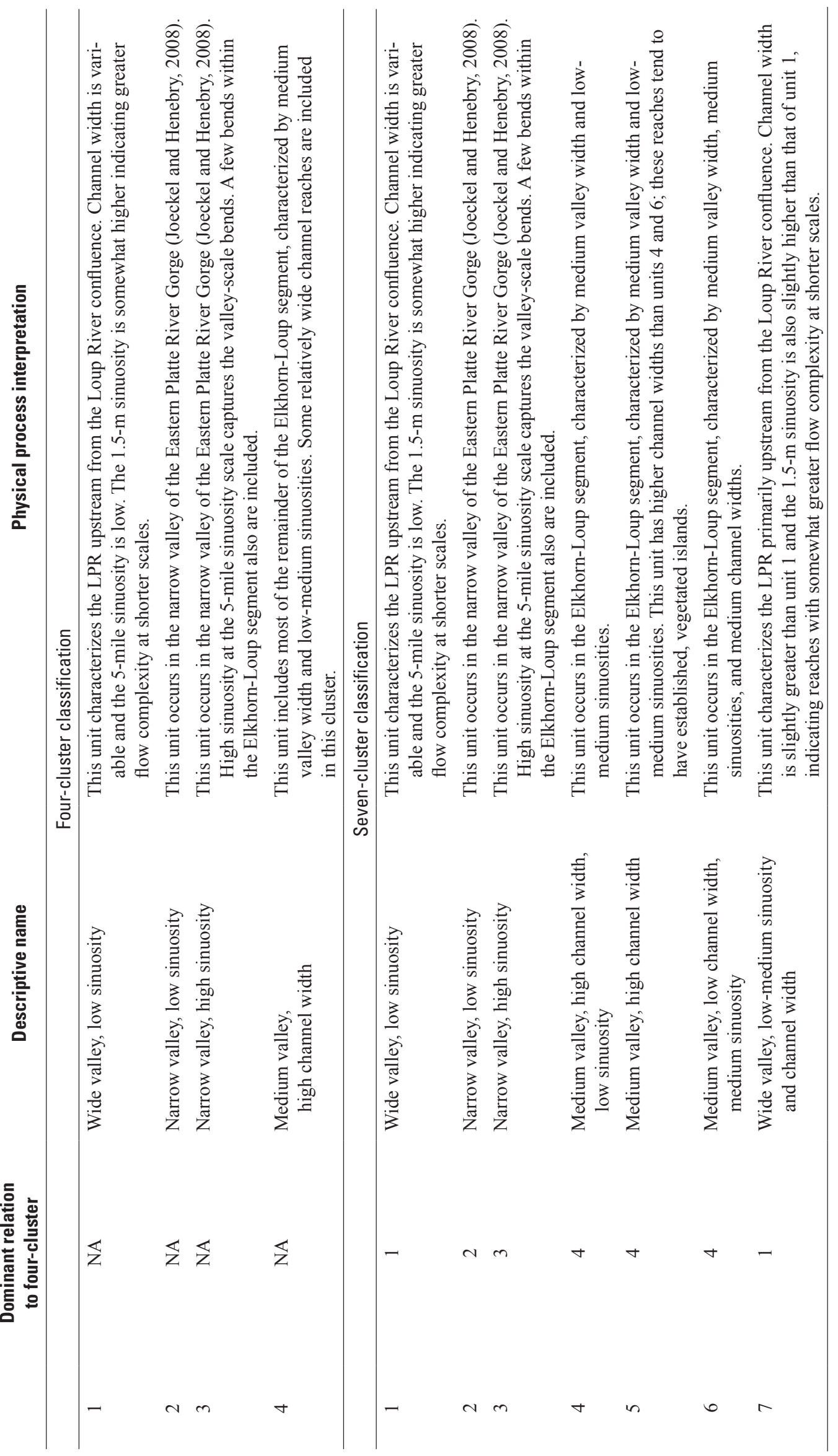


Table 5. Percent of classification reaches in Lower Platte River segments from Elliott and others, 2009.

[ ${ }^{1}$ Class 1 of seven-cluster classification has only 1 member, original classifcation extended upstream from the Loup River.]

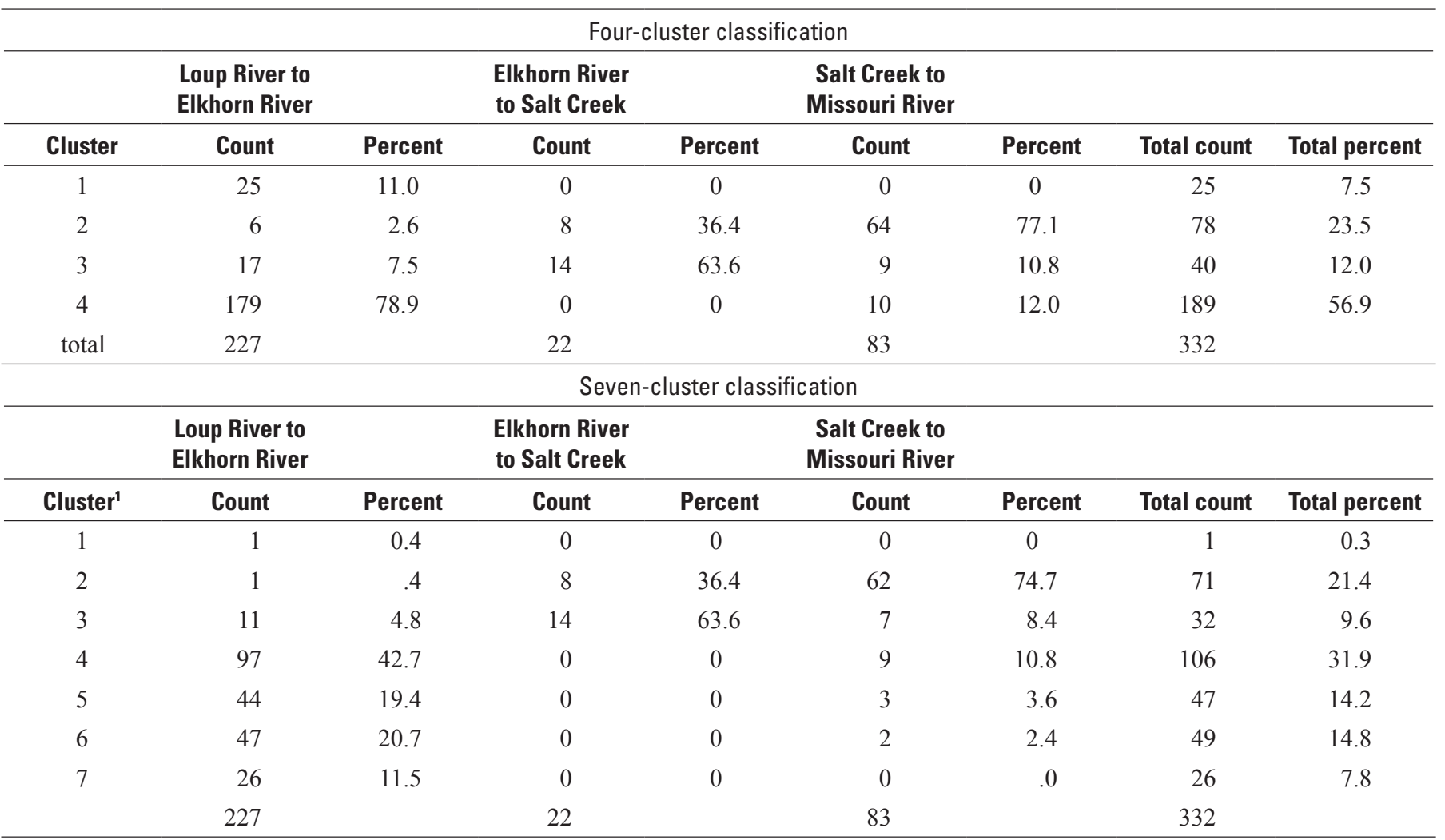

Table 6. Nests per mile in Lower Platte River segments.

[nest data from Brown and Jorgenson, 2008 and 2009; and Joel Jorgenson, unpublished data, Nebraska Game and Parks Commission, 2009]

\begin{tabular}{lcccccc}
\hline \multicolumn{1}{c}{ Segment } & $\mathbf{2 0 0 6}$ & $\mathbf{2 0 0 7}$ & $\mathbf{2 0 0 8}$ & $\mathbf{2 0 0 9}$ & All years, total & All years, average \\
\hline Loup River to Elkhorn River & 0.7 & 0.1 & 0.9 & 1.7 & 3.4 & 0.9 \\
Elkhorn River to Salt Creek & 2.0 & .0 & .9 & 8.4 & 11.3 & 2.8 \\
Salt Creek to Missouri River & .8 & .3 & 3.6 & 5.0 & 9.7 & 2.4 \\
Lower Platte River average & .8 & .2 & 1.6 & 3.0 & 5.5 \\
\hline
\end{tabular}


light vegetation and dry sand were added together as a single class to recognize the potential for the light vegetation class to convert to dry sand either through scouring of vegetation or manual vegetation removal. Reaches with high braid intensity (equal to or greater than 15 channels) were also plotted as a function of channel width. Widths at reaches including all nest locations for 2006 through 2008 were also included (nest locations from Joel Jorgenson, unpub. data. Nebraska Game and Parks Commission, 2008).

Similar to findings on the Missouri River by Biedenharn and others, 2001, cumulative distributions of channel width indicate that based on the 2006 NAIP aerial photography reaches dominated by dark vegetation (interpreted as islands) are the widest reaches on the Lower Platte River (Biedenharn and others, 2001). Reaches with high proportions of dry sand and dry sand plus light vegetation are narrower than other wet sand reaches (fig. 9). Highly braided reaches were wide, but narrower than reaches dominated by dark vegetation. Tern and Plover nesting locations from 2006 through 2008 occur in reaches that were narrower than the highly braided or dark vegetation dominant reaches, but wider than the reaches dominated by dry sand or dry sand and light vegetation (fig. 9).

\section{Discussion}

Variability in discharge, particularly in the occurrence high flow events, changes the extent and locations of emergent sandbar habitat on the Lower Platte River (Brown and Jorgenson, 2009). Analysis of historical streamflow records (from 1895 to 2006) on the Lower Platte River determined that the 1996 to 2000 period was unusually wet and the 2000 to 2006 period was a period of drought (Ginting and others, 2007). This report primarily addresses channel conditions in July of 2006 when the aerial photography used in the analysis was flown. The 2006 aerial photography follows six years of low flows on the Lower Platte River and its tributaries and channel conditions can be considered indicative of habitat

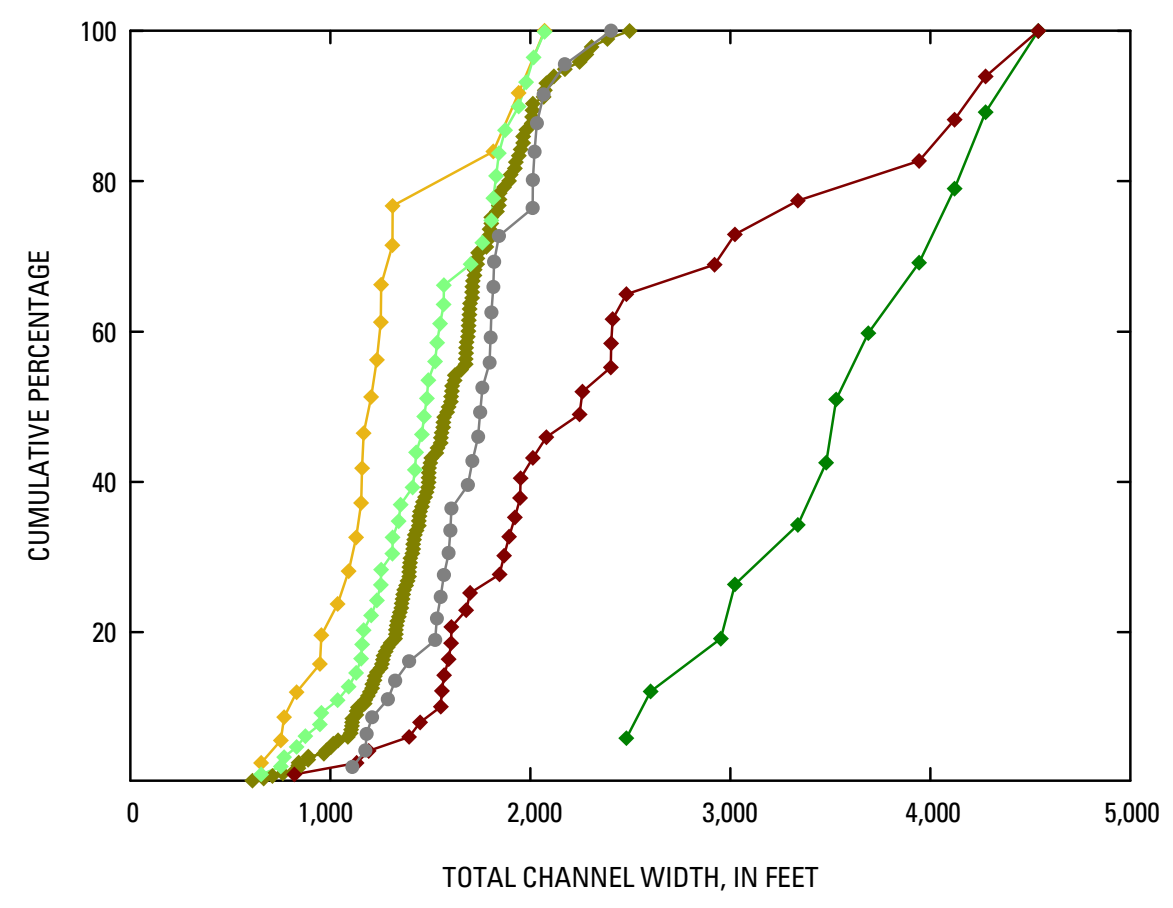

EXPLANATION

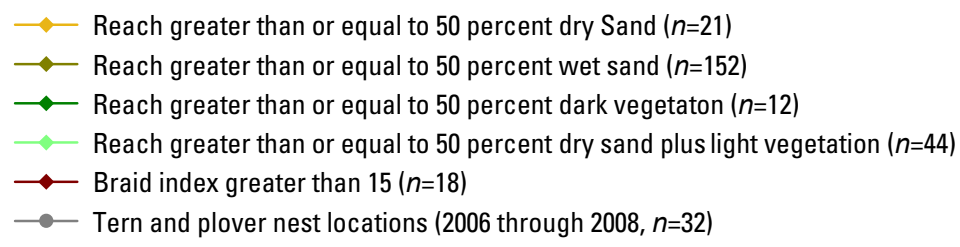

Figure 9. Cumulative distribution of channel width and occurrence of habitat units. 
during drought conditions. High flows on the Lower Platte River in 2008 illustrated the capability of high flow events to transport and deposit sediment in the channel (Brown and Jorgenson, 2009). An assessment of aerial photography or channel topography post-2006 would be useful to understand changes in sandbar habitat after high flow events; however, such an analysis is beyond the scope of this report. Variability in flow conditions during aerial photography flights remains a challenge for using imagery to measure in-channel habitats on the Lower Platte River. Methods that have the potential to be more successful at assessing in-channel nesting habitat availability and change require finer-resolution data than available from imagery. Survey methods that collect elevation information would be needed to identify and understand emergent sandbar habitat dynamics on the Lower Platte River. Methods that collect elevation information include standard surveys, high resolution Global Position System surveys (GPS), and Light Detection and Ranging measurements (LiDAR). Advances in technology in LiDAR collection are ongoing and successful application of LiDAR techniques depends on ground and flow conditions at the time of data collection. Airborne or terrestrial (LiDAR) provides useful in-channel elevation data when collected during low-flow conditions. Bathymetric LiDAR may be useful if flow conditions and turbidity on the Lower Platte River allowed for optimal data collection. Standard ground surveys, particularly those using high-resolution GPS could also provide detailed elevation data for sandbar habitat, although they tend to be labor intensive and expensive to conduct.

Recent research has highlighted the importance of vegetation in braided, transitional, and meandering channel morphodynamics (Gran and Paola, 2001; Beechie and others, 2006; Tal and Paola, 2010). Laboratory experiments indicate that vegetation can slow the rate of widening and creation of channel cutoffs. Moreover, colonizing vegetation can stabilize bars scoured by high discharge, effectively controlling the patterns of erosion and deposition within channels in braided systems (Tal and Paola, 2010). Improved understanding of emergent sandbar dynamics on the Lower Platte River may benefit from investigations of the interplay between discharge events, bar formation, and vegetation stabilization.

A key data gap for the Lower Platte River is spatial information about existing bank stabilization structures. The Lower Platte River Cumulative Impact Study seeks to evaluate the cumulative effect of bank stabilization on physical habitats in the Lower Platte River, yet consistent and detailed information on the status of bank structures is presently (2010) not available for the Lower Platte River. This limits the ability to document direct relations between bank stabilization and physical habitat types and dynamics. The design, materials, and scale of bank stabilization structures can be highly variable and the effects on in-channel habitats can be expected to vary as well. For example, a bank stabilization project that extends for several miles would be expected to affect the channel and emergent sandbar habitats in different ways than a smaller (tens to hundreds of feet long) localized project built to protect infrastructure such as a bridge or pipeline crossing. Locally, bank stabilization may inhibit bank erosion, but cause scouring and instability downstream from the structure.

Bank erosion is a natural process on large rivers and has been determined to be beneficial to ecosystem functions (Florsheim and others, 2008). Although the Lower Platte River has generally experienced channel narrowing and has remained primarily within its mid- $19^{\text {th }}$ century channel belt downstream from the Loup and Elkhorn Rivers, measurable lateral migration by bank erosion has occurred (Joeckel and Henebry, 2008). Bank erosion provides a potential sediment source and space to accommodate sandbar habitat on the Lower Platte River.

Bank stabilization also may indirectly result in changes in channel habitat used by terns and plovers on the Platte River. Large woody debris has been demonstrated to be related to invertebrate production in river systems (Benke and Wallace, 2003) and to the development of channel complexity in large rivers, including sandbars and islands within an active river channel (Abbe and Montogomery, 1996; Gurnell and others, 2005; Latterell and Naiman, 2007). Woody debris may not have been a substantial ecosystem component of the Central Platte River since the mid-19th century (Johnson, 1994), however downstream from the Loup River on the Lower Platte, historical records indicate that woody vegetation in the river corridor always has been more abundant than upstream (Joeckel and Henebry, 2008). One may infer that with active bank erosion and a forested riparian corridor woody debris would naturally be a substantial component of aquatic habitat on the Lower Platte River. On the Missouri, Mississippi and Ohio Rivers, overall wood distribution was documented to be patchy and higher in density along natural or unprotected shorelines compared to stabilized banks (Angradi and others, 2004; Angradi and others, 2010). Large woody debris potentially could increase insect and small fish production and increase foraging habitat on the Lower Platte River. The Lower Platte River provides important foraging habitat for least terns and plovers that nest on in-channel habitat and those that nest in adjacent off-channel habitat (Lott, 2006; Brown and Jorgenson, 2008, 2009).

Channel sinuosity relates to curvature, flow separation, and hydraulic diversity and has therefore been used frequently as an indicator of hydraulic habitat diversity (Nakamura and Swanson, 1994; Barbour and others, 1999; Nakano and Nakamura, 2008). In meandering channels sinuosity has been linked to the location of flow convergence and divergence (Da Silva and others, 2006) and the locations of pools and bars within bends (Whiting and Dietrich, 1993). Investigations in the field and laboratory flumes have correlated variations in channel width in meandering channels to bend curvature and the formation of mid-channel bars (Luchi and others, 2010a; Luchi and others, 2010b). Channel sinuosity at fine-scales in transitional braided rivers such as the Lower Platte River may contribute to the locations of channel bifurcations, midchannel bar locations (potential emergent sandbar habitat), regions of active bank erosion, and the general diversity of 
in-channel hydraulic habitats. Sinuosity in large rivers has also been linked to the presence of stored wood and wood recruitment through lateral bank erosion (Lassettre and others, 2008). Although specific links between channel sinuosity and habitat diversity have not been established in the Lower Platte River, these studies indicate that channel sinuosity can be useful as an indirect indicator of diversity.

The total channel width and habitat analysis (fig. 9) indicates that reaches with high proportions of dry sand and dry sand plus light vegetation occur in narrower channels. Narrow channels have sufficient transport capacity to maintain sandbars under recent (2006) flow regimes. Narrow channels are likely to be most amenable to maintaining tern and plover habitat in the Lower Platte River. An analysis of sandbar persistence within narrower Lower Platte River reaches throughout multiple years of photography would test this hypothesis.

\section{Summary}

This report examines channel habitat characteristics and the longitudinal multivariate classification in Elliott and others (2009) for broad segments of the Lower Platte River and presents a new analysis of total channel width and habitat variables. Detailed descriptions of data collection and classification methods are described in Elliott and others (2009). Because of fluctuating discharges within the NAIP imagery, in-channel habitat measurements were not made under consistent hydrologic conditions and must be considered general estimates of channel condition in late July 2006. Channel features such as dark vegetation, light vegetation, and dry sand appear to be relatively less sensitive than deep water and wet sand to changes in discharge through a hydropeaking cycle, whereas percent deep water and wet sand are channel characteristics that appear to be sensitive to discharge. Aggregating habitat features for broad river segments also may dampen some of the variation in habitats because of discharge fluctuations.

The Platte River segment from the Loup River to the Elkhorn River contains the widest reaches and the most variability in reach width on the Lower Platte River. This segment also has the largest valley width. Braid intensity is higher in this reach and dark vegetation (islands) occur in a higher percentage of reaches. The Lower Platte segment downstream from the Loup River primarily contains cluster 4 of the four-cluster classification and clusters 4,5 , and 6 of the seven-cluster classification (fig. 8, table 5). Cluster 4 is characterized by an intermediate valley width, low-to medium sinuosity and high channel widths.

The relatively short (6.9-mile) segment of river between the Elkhorn River and Salt Creek has a fairly low valley width and high sinuosites at larger scales. The segment between the Elkhorn River and Salt Creek consists of clusters 2 and 3 from the four- and seven-cluster classifications with 36.4 and
63.6 percent of the reaches respectively (fig. 8 , table 5). These reaches occur in narrow valleys and include reaches with low and high sinuosity.

The segment from Salt Creek to the Missouri River is dominated by cluster 2 of the four-cluster and cluster 2 of the seven-cluster classification (fig. 8, table 5). Cluster 2 reaches have narrow valleys and generally low sinuosites in the fourcluster and seven-cluster classifications.

Overall trends in channel width indicate that reaches dominated by dark vegetation (islands) are the widest on the Lower Platte River. Reaches with high percentages of dry sand and dry sand plus light vegetation are the narrowest reaches on the Lower Platte River. This indicates that narrow channel reaches have sufficient transport capacity to maintain sandbars under recent (2006) flow regimes and likely are most amenable to maintaining tern and plover habitat in the Lower Platte River.

Tern and plover nest sites from 2006 through 2008 occurred in reaches that were narrower than reaches with large percentages of dark vegetation or were highly braided. There were more nests per mile in the segments of the Lower Platte River downstream from the Elkhorn River. The multiscale classification and tern and plover nesting data from 2006 through 2008 indicated relative nesting selection of cluster 2 reaches among the four-cluster classification and reaches containing clusters 2,3 , and 6 from the seven-cluster classification. These classes, with the exception of cluster 6 are common downstream from the Elkhorn River.

Further investigations into the dynamics of emergent sandbar habitat and the effects of bank stabilization on in-channel habitats will require the collection and analysis of new data, particularly more detailed elevation information, and a detailed assessment of existing bank stabilization structures. It is likely that the increase in discharge and sediment from the Elkhorn River and Salt Creek, and potential inputs of sediment and woody debris from eroding channel banks, are important in creating and maintaining diverse in-channel habitats, including emergent sandbar nesting habitat on the Lower Platte River.

\section{References Cited}

Abbe, T.B., and Montogomery, D.R., 1996, Large woody debris jams, channel hydraulics, and habitat formation in large rivers: Regulated Rivers: Research and Management, v. 12, p. 201-221.

Angradi, T.R., Schweiger, E.W., Bolgrien, D.W., Ismert, P., and Selle, T., 2004, Bank stabilization, riparian land use and the distribution of large woody debris in a regulated reach of the upper Missouri River, North Dakota, USA: River Research and Applications, v. 20, no. 7, p. 829-846. 
Angradi, T.R., Taylor, D.L., Jicha, T.M., Bolgrien, D.W., Pearson, M.S., and Hill, B.H., 2010, Littoral and shoreline wood in mid-continent Great Rivers (USA): River Research and Applications, v. 26, p. 261-278.

Barbour, M.T., Gerritsen, J., Snyder, B.D., and Stribling, J.B., 1999, Rapid bioassessment protocols for use in streams and wadeable rivers-Periphyton, benthic macroinvertebrates and fish: U.S. Environmental Protection Agency, Office of Water EPA 841-B-99-002, 339 p.

Beechie, T.J., Liermann, M., Pollock, M.M., Baker, S., and Davies, J., 2006, Channel pattern and river-floodplain dynamics in forested mountain river systems: Geomorphology, v. 78, p. 124-141.

Benke, A.C., and Wallace, J.B., eds., 2003, Influence of wood on invertebrate communities in streams and rivers: Bethesda, Maryland, American Fisheries Society, v. 37, 149-177 p.

Biedenharn, D.S., Soileau, R.S., Hubbard, L.C., Hoffman, P.H., Thorne, C.R., and Bromley, C.C., 2001, Missouri River-fort peck dam to ponca state park geomorphological assessment related to bank stabilization: U.S. Army Corps of Engineers, 136 p.

Brown, M.B., and Jorgenson, J.G., 2008, 2008 Interior least tern and piping plover monitoring, research, management, and outreach report for the Lower Platte River, Nebraska, Joint report on the Tern and Plover Conservation Partnership and the Nebraska Game and Parks Commission Nongame Bird Program, p. 1-60.

Brown, M.B., and Jorgenson, J.G., 2009, 2009 Interior Least Tern and Piping Plover monitoring, research, management, and outreach report for the Lower Platte River, Nebraska: Tern and Plover Conservation Partnership and Nebraska Game and Parks Commission Nongame Bird Program, 77 p.

Da Silva, A.M., El-Tahawy, T., and Tape, W.D., 2006, Variation of flow patterns with sinuosity in sine-generated meandering streams: Journal of Hydraulic Engineering, v. 132 , no. 10 , p. $1,003-1,014$.

Egozi, R., and Ashmore, P., 2008, Defining and measuring braiding intensity: Earth Surface Processes and Landforms, v. 33 , p. 2,121-2,138.

Elliott, C.M., Huhmann, B., and Jacobson, R.B., 2009, Geomorphic classification of the Lower Platte River, Nebraska: U.S. Geological Survey Scientific Investigations Report 2009-5198, $30 \mathrm{p}$.

Elliott, C.M., and Jacobson, R.B., 2006, Geomorphic classification and assessment of channel dynamics in the Missouri National Recreational River, South Dakota and Nebraska: U.S. Geological Survey Scientific Investigations Report 2006-5313, 66 p.
Florsheim, J.L., Mount, J.F., and Chin, A., 2008, Bank erosion as a desirable attribute of rivers: Bioscience, v. 58 , no. 6 , p. 519-529.

Gesch, D.B., ed., 2007, The National Elevation Dataset (2 ed.): Bethesda, Maryland, Americal Society for Photogrammetry and Remote Sensing, 99-118 p.

Gesch, D.B., Oimoen, M., Greenlee, S., Nelson, C., Steuck, M., and Tyler, D., 2002, The National Elevation Dataset: Photogrammetric Engineering and Remote Sensing, v. 68, no. 1 , p. 5-11.

Ginting, D., Zelt, R.B., and Linard, J.I., 2007, Temporal differences in the hydrologic regime of the lower Platte River, Nebraska, 1895-2006: U.S. Geological Survey Scientific Investigations Report 2007-5267, 43 p.

Gran, K., and Paola, C., 2001, Riparian vegetation controls on braided stream dynamics: Water Resources Research, v. 37, no. 12 , p. $3,275-3,283$.

Gurnell, A., Tockner, K., P., E., and Petts, G., 2005, Effects of deposited wood on biocomplexity of river corridors: Frontiers in Ecology and the Environment, v. 3, no. 7, p. $377-382$.

Hadley, R.F., Karlinger, M.R., Burns, A.W., and Eschner, T.R., 1987, Water development and associated hydrologic changes in the Platte River, Nebraska, U.S.A.: Regulated Rivers: Research and Management, v. 1, p. 331-341.

Joeckel, R.M., and Henebry, G.M., 2008, Channel and island change in the Lower Platte River, eastern Nebraska, USA: 1855-2005: Geomorphology, v. 102, p. 407-418.

Johnson, W.C., 1994, Woodland expansions in the Platte River, Nebraska: Patterns and causes: Ecological Monographs, v. 64, no. 1, p. 45-84.

Johnson, W.C., 1997, Equilbrium response of riparian vegetation to flow regulation in the Platte River: Regulated Rivers: Research and Management, v. 13, p. 403-415.

Kirsch, E.M., 1996, Habitat selection and productivity of Least Terns on the Lower Platte River, Nebraska: Wildlife Monographs, v. 132, p. 3-48.

Lassettre, N.S., Piégay, H., Dufour, S., and Rollet, A., 2008, Decadal changes in distribution and frequency of wood in a free meandering river, the Ain River, France: Earth Surface Processes and Landforms, v. 33, p. 1,098-1,112.

Latterell, J.J., and Naiman, R., 2007, Sources and dynamics of large logs in a temperate floodplain river: Ecological Applications, v. 17, no. 4, p. 1,127-1,141. 
Lingle, G.R., 1993, Nest success and flow relationships on the Central Platte River, in Higgins, K.F., and Brashier, M.R., eds., The Missouri River and Its Tributaries: Piping Plover and Least Tern Symposium: Brookings, South Dakota, South Dakota State University, p. 69-72.

Lott, C.A., 2006, Distribution and abundance of the interior population of the Least Tern (Sterna antillarum), 2005: U.S. Army Corps of Engineers Engineer Research and Development Center ERDC/EL TR-06-13, 100 p.

Luchi, R., Hooke, J.M., Zolezzi, G., and Bertoldi, W., 2010a, Width variations and mid-channel bar inception in meanders: River Bollin (UK): Geomorphology, v. 119, p. $1-8$.

Luchi, R., Zolezzi, G., and Tubino, M., 2010b, Modelling mid-channel bars in meandering channels: Earth Surface Processes and Landforms, no. 35, p. 902-917.

Manly, B.F.J., McDonald, L.L., Thomas, D.L., McDonald, T.L., and Erickson, W.P., 2002, Resource selection by animals- Statistical design and analysis for field studies (2 ed.): Dordrecdt, the Netherlands, Kluwer Academic Publishers, $221 \mathrm{p}$.

Murphy, P.J., Randle, T.J., Fotherby, L.M., and Daraio, J.A., 2004, The Platte River channel: history and restoration: U.S. Department of the Interior, Bureau of Reclamation 310 p.

Nakamura, F., and Swanson, F.J., 1994, Distribution of coarse woody debris in a mountain stream, Western Cascade Range, Oregon: Canadian Journal of Forest Research, v. 24, no. 12 , p. $2,395-2,403$.

Nakano, D., and Nakamura, F., 2008, The significance of meandering channel morphology on the diversity and abundance of macroinvertebrates in a lowland river in Japan: Aquatic Conservation: Marine and Freshwater Ecosystems, v. 18, no. 5, p. 780-798.

Randle, T.J., and Samad, M.A., 2003, Platte River flow and sediment transport between North Platte and Grand Island, Nebraska (1895-1999): U.S. Department of the Interior, Bureau of Reclamation $83 \mathrm{p}$.

Sidle, J.G., Carlson, D.E., Kirsch, E.M., and Dinan, J.J., 1992, Flooding: Mortality and habitat renewal for least terns and piping plovers: Colonial Waterbirds, v. 15, no. 1 , p. 132-136.

Simons and Associates Inc., 2000, Physical history of the Platte River in Nebraska: Focusing upon flow, sediment transport, geomorphology, and vegetation: Prepared for U.S. Department of Interior, Platte River EIS Office, 195 p.

Tal, M., and Paola, C., 2010, Effects of vegetation on channel morphodynamics: results and insights from laboratory experiments: Earth Surface Processes and Landforms, v. 35, p. 1,014-2,028.
U.S. Fish and Wildlife Service, 2006, Biological opinion on the Platte River recovery implementation program: U.S. Fish and Wildlife Service, 330 p.

Whiting, P.J., and Dietrich, W.E., 1993, Experimental studies of bed topography and flow patterns inlargeamplitude meanders: Water Resources Research, v. 29, no. 11, p. $3,605-3,614$.

Williams, G.P., 1978, The case of the shrinking channels- the North Platte and Platte Rivers in Nebraska: U.S. Geological Survey Circular 781, 48 p.

Ziewitz, J.W., Sidle, J.G., and Dinan, J.J., 1992, Habitat conservation for nesting least terns and piping plovers on the Platte River, Nebraska: The Prairie Naturalist, v. 24, no. 1, p. 1-20.
Publishing support provided by Rolla and Lafayette Publishing Service Centers 
